\title{
Confocal analysis of cholinergic and dopaminergic inputs onto pyramidal cells in the prefrontal cortex of rodents
}

\author{
Zi-Wei Zhang ${ }^{1,2}$, Mark W. Burke ${ }^{1}$, Nicole Calakos ${ }^{3}$, Jean-Martin Beaulieu ${ }^{4}$ and Elvire Vaucher ${ }^{*}$ \\ School of Optometry, Université de Montréal, Montréal, OC, Canada \\ Department of Physiology, Université de Montréal, Montréal, OC, Canada \\ ${ }^{3}$ Department of Neurobiology, Division of Neurology, Center for Translational Neuroscience, Duke University, Durham, NC, USA \\ ${ }^{4}$ Department of Psychiatry and Neuroscience, Université de Laval/Centre de recherche Université Laval Robert-Giffard, Québec, QC, Canada
}

\section{Edited by:}

Kathleen S. Rockland, Massachusetts

Institute of Technology, USA

\section{Reviewed by:}

Gregor Rainer, Max Planck Institute for Biological Cybernetics, Germany

Naguib Mechawar, McGill University,

Canada

\section{${ }^{*}$ Correspondence:}

Elvire Vaucher, School of Optometry,

University of Montreal, CP6128

succursale centre-ville, Montreal, QC

H3C 3J7, Canada.

e-mail: elvire.vaucher@umontreal.ca
Cholinergic and dopaminergic projections to the rat medial prefrontal cortex (mPFC) are both involved in cognitive functions including attention. These neuronal systems modulate mPFC neuronal activity mainly through diffuse transmission. In order to better understand the anatomical level of influence of these systems, confocal microscopy with triple-fluorescent immunolabeling was used in three subregions of the mPFC of rats and Drd1a-tdTomato/Drd2-EGFP transgenic mice. The zone of interaction was defined as a reciprocal microproximity between dopaminergic and cholinergic axonal segments as well as pyramidal neurons. The density of varicosities, along these segments was considered as a possible activity-dependant morphological feature. The percentage of cholinergic and dopaminergic fibers in microproximity ranged from 12 to $40 \%$ depending on the layer and mPFC subregion. The cholinergic system appeared to have more influence on dopaminergic fibers since a larger proportion of the dopaminergic fibers were within microproximity to cholinergic fibers. The density of both cholinergic and dopaminergic varicosities was significantly elevated within microproximities. The main results indicate that the cholinergic and dopaminergic systems converge on pyramidal cells in mPFC particularly in the layer V. In transgenic mice $93 \%$ of the pyramidal cells expressed the transgenic marker for Drd2 expression, but only 22\% expressed the maker for Drd1ar expression. Data presented here suggest that the modulation of MPFC by dopaminergic fibers would be mostly inhibitory and localized at the output level whereas the cholinergic modulation would be exerted at the input and output level both through direct interaction with pyramidal cells and dopaminergic fibers.

Keywords: acetylcholine, cingulate cortex, dopamine, prelimbic cortex, infralimbic cortex, diffuse transmission

\section{INTRODUCTION}

The rat medial prefrontal cortex (mPFC) is involved in a variety of cognitive functions including attentional processes, working memory, behavioral flexibility and inhibition (Heidbreder and Groenewegen, 2003; Gabbott et al., 2005; Briand et al., 2007). Its three main anatomical subdivisions, the anterior cingulate (Cg1), the prelimbic (PrL) and the infralimbic (IL) areas (Vertes, 2004, 2006; Tavares and Correa, 2006) receive long ascending projections from cholinergic neurons of the basal forebrain (BF) (Golmayo et al., 2003; Henny and Jones, 2008) and from dopaminergic neurons of the ventral tegmental area (VTA). Both neuronal systems modulate mPFC activity and attentional performance (Gill et al., 2000; Golmayo et al., 2003; Sarter et al., 2003; Chudasama et al., 2004; Dalley et al., 2004; Sarter et al., 2005; Goto et al., 2007; Del Arco and Mora, 2009). Particularly, acetylcholine (ACh) plays an essential role in the top-down control of attention (Sarter et al., 2006), orienting and retention in working memory tasks (Broersen et al., 1995; Steckler et al., 1998; Thienel et al., 2009). Dopamine (DA) plays a major role in motor control, selective attention, impulsivity, executive control (Robbins, 2005; Chen et al., 2007; Lapish et al., 2007; Li et al., 2007; Thienel et al., 2009) and has a "finetuning" effect for optimum cognitive performance (Granon et al.,
2000; Tzschentke, 2001). Both ACh and DA systems are involved in pathologies such as Alzheimer's disease, attention deficit hyperactivity disorder and schizophrenia.

There is a growing body of pharmacological evidence supporting the interaction between $\mathrm{ACh}$ and DA in the rat prefrontal cortex. Increase of DA release by ACh in the prefrontal cortex seems to happen at a local level through nicotinic receptors (nAChR) (Rao et al., 2003; Cao et al., 2005; Rossi et al., 2005; Shearman et al., 2005). Inhibition of ACh esterase (Shearman et al., 2006) or stimulation of muscarinic receptors (Perry et al., 2001; Ichikawa et al., 2002) also induced the release of DA in the mPFC. Likewise, DA has been shown to influence ACh transmission (Laplante et al., 2004). Activation of $D_{1}$ dopaminergic receptors $\left(D_{1} R\right)$ has been proposed to exert a tonic, facilitatory influence upon cholinergic transmission (Yang and Mogenson, 1990). Extracellular levels of ACh were robustly enhanced in the PFC following systemic administration of the $\mathrm{D}_{1} \mathrm{R}$ agonist SKF82958 (Di Cara et al., 2007) and the $\mathrm{D}_{3} \mathrm{R}$ antagonists (Lacroix et al., 2006). However, due to the systemic infusion of these dopamine agonists/antagonists, it is not clear if the modulation of ACh release by DA in these experiments occurred at a local level or is part of a larger neural circuitry modulation. 
It has also been shown that both DA and ACh modulate the activity of pyramidal neurons and the functional output of the MPFC (Spruston, 2008). The excitatory post-synaptic potential (EPSP) of pyramidal neurons in layer $\mathrm{V}$ of the rat $\mathrm{mPFC}$ can be attenuated by the $\mathrm{D}_{1} \mathrm{R}$ agonist SKF 81297 in vitro (Rotaru et al., 2007). DA has been shown to have an inhibitory effect on layer $\mathrm{V}$ pyramidal cells in the rat $\mathrm{mPFC}$ through $\mathrm{D}_{2} \mathrm{R}$ activation in vitro (Gulledge and Jaffe, 1998; Steketee, 2003) and in vivo (Goto and Grace, 2005). In addition, $\mathrm{M}_{1} \mathrm{mAChR}$ stimulation in layer $\mathrm{V}$ pyramidal cells of the rodent PrL/IL cortex produces a strong depolarization and leads to tonic firing by dramatically enhancing the summation of EPSP (Carr and Surmeier, 2007). In slices from rat PrL, nicotinic and muscarinic agonists modulate excitatory synaptic transmission, indicating the ascending cholinergic systems might participate in information processing in the PrL via control of ongoing excitation to pyramidal cells (Vidal and Changeux, 1993).

Evidence for the physiological basis for the interaction between ACh, DA, and glutamatergic pyramidal cells is extensive, however the neuroanatomical correlate within the mPFC supporting this interaction has not been established. Diffuse transmission, rather than synaptic transmission, is a widely occurring and well-documented phenomenon for ACh and DA in mPFC (Descarries et al., 1997; Descarries, 1998; Descarries and Mechawar, 2000; Yamasaki et al., 2010). The current study investigated the three-dimensional anatomical relationship among the cholinergic system, dopaminergic system, and pyramidal cells by quantifying the microproximity among these three neuronal elements in the mPFC of rats using confocal laser-scanning microscopy. Microproximity between dopaminergic and cholinergic fibers or pyramidal cells (defined as relationships with a gap less than $3 \mu \mathrm{m}$ between two neuronal elements) was considered as a possible functional interaction zone. As the axonal varicosities are the site of neurotransmitters release, the number of en passant varicosities within the axonal segments sharing microproximity was quantified, as an index of possible functional activity. As well, the expression of $\mathrm{D}_{1} \mathrm{aR}$ and $\mathrm{D}_{2} \mathrm{R}$ by pyramidal cells and cholinergic fibers within the MPFC was examined since these receptors are implicated in the top-down modulation of subcortical areas via descending PFC (Onn et al., 2006; Del Arco and Mora, 2009). For this purpose we used Drd1a-tdTomato/
Drd2-EGFP double BAC-transgenic mice (Gong et al., 2003; Shuen et al., 2008) expressing tdTomato as a reporter for $\mathrm{D}_{1}$ aR-expressing neurons and EGFP as a reporter for $\mathrm{D}_{2} \mathrm{R}$-expressing neurons. These mice enabled us to overcome limitations imposed by the lack of readily available antibodies that discriminate between these receptor subtypes. Anatomical relationships were investigated within different subregions of the mPFC (PrL, IL, Cg1) as well as in the layer receiving cortico-cortical input (II/III) and the output layer (V) of the mPFC to determine a possible regional specificity of the different neuronal systems.

\section{MATERIALS AND METHODS ANIMAL PREPARATION}

Six Male Long Evans rats (300-325 g, Université de Montréal obtained from Charles River Canada (St-Constant, Québec, Canada) and three Drd1a-tdTomato Drd2-EGFP double transgenic mice (Gong et al., 2003; Shuen et al., 2008) (Université Laval) were housed in a temperature-controlled room $\left(21-25^{\circ} \mathrm{C}\right)$ under natural daylight, and had free access to food and water. Animals were deeply anesthetized with pentobarbital ( $54 \mathrm{mg} / \mathrm{kg}$ body weight i.p.) and then were perfused transcardially with $4 \%$ paraformaldehyde at room temperature. After perfusion, brains were harvested and post fixed for $2 \mathrm{~h}$ in fresh fixative. Serial coronal vibratome sections $(35-\mu \mathrm{m}$ thick) were cut and collected in $0.1 \mathrm{M}$ phosphate buffer (PBS, $\mathrm{pH}=7.4)$, then stored in antifreeze ( $30 \%$ glycerol, $30 \%$ ethylene glycol, $40 \% \mathrm{NaPB} 0.24 \mathrm{M}$ ) solution at $-20^{\circ} \mathrm{C}$ until further use. All procedures were approved by the local Animal Care Committee Université de Montréal (rats) and Université Laval (mice) and were conducted in accordance with the guidelines of the Canadian Council on Animal Care.

\section{IMMUNOCYTOCHEMISTRY}

Sections were thoroughly washed in $0.1 \mathrm{M}$ PBS, and then incubated in $0.3 \% \mathrm{H}_{2} \mathrm{O}_{2}$ in $0.1 \mathrm{M}$ PBS. The sections were then washed and incubated in $1.5 \%$ donkey serum in PBS-T $(0.1 \mathrm{M}$ phosphate buffer, $\mathrm{pH} 7.4$ and $0.25 \%$ triton $\mathrm{x}-100$ ) for $1 \mathrm{~h}$. Rat brain sections were incubated in a cocktail of primary antibodies for $48 \mathrm{~h}$ at $4^{\circ} \mathrm{C}$ (Table 1): anti-choline acetyltransferase (ChAT, 1:200; Chemicon, Billerica, MA, USA) for cholinergic fibers (Dotigny et al., 2008;

Table 1 | Combination of primary and secondary antibodies for triple-fluorescent staining procedures.

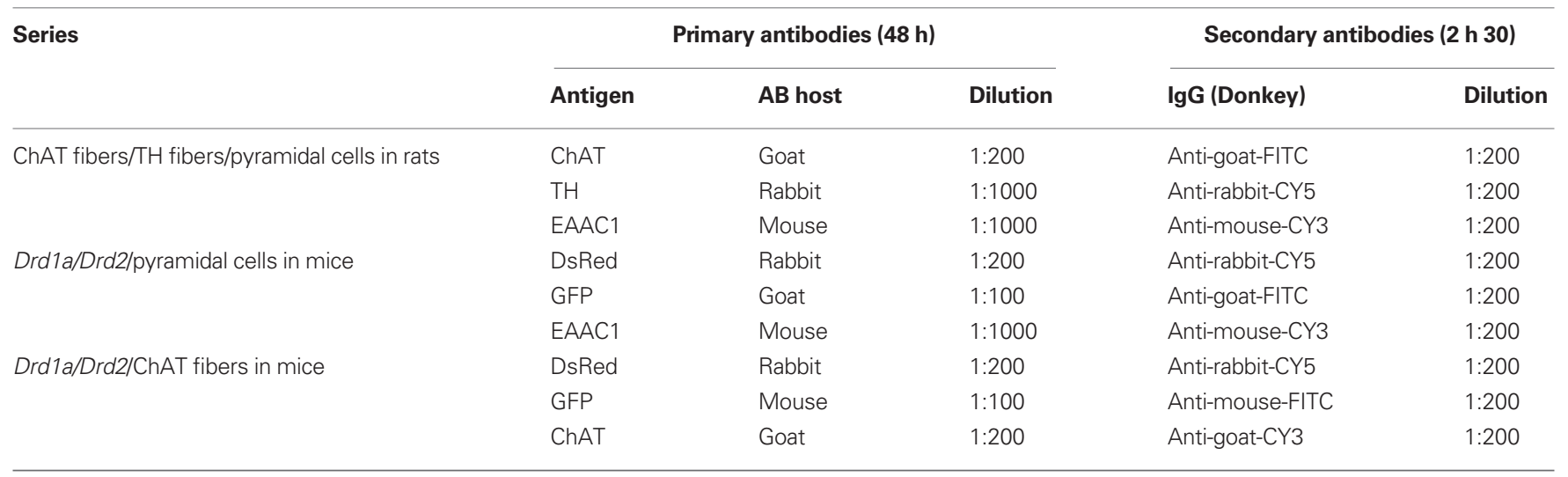

Abbreviations: ChAT, choline acetyltransferase; EAAC1, excitatory amino acid carrier 1 protein; TH, tyrosine hydroxylase. 
Vaucher et al., 1997); anti-tyrosine hydroxylase (TH, 1:1000; PelFreez Biologicals, Rogers, AR, USA) for dopaminergic fibers (Miner et al., 2003) and anti-glutamate transporter (EAAC1, excitatory amino acid carrier 1 protein, 1:1000, Chemicon, Billerica, MA, USA) for pyramidal cells (Rothstein et al., 1994; He et al., 2000; Furuta et al., 2003; Dotigny et al., 2008). Moreover, the pyramidal cell analysis was performed based on the pyramidal morphology of the EAAC1 stained cells. Triple immunolabeling of $\mathrm{D}_{1} \mathrm{aR}$-expressing neurons (amplification of the TomatoRed signal with anti-DsRed Polyclonal Antibody Rabbit, 1:200, Clonetech, Mountain View, CA, USA), $D_{2}$ R-expressing neurons (amplification of the GFP signal with monoclonal mouse anti-GFP (B-2), 1:100, SantaCruz, Santa Cruz, CA, USA), and either pyramidal cells or ChAT fibers were carried out on adjacent sections. After washing, the sections were incubated in secondary antibodies conjugated with fluorophore CY3, FITC, CY5 (Jackson Immunoresearch, West Grove, PA, USA) for $2 \mathrm{~h}$ and $30 \mathrm{~min}$. Mouse tissue was incubated with Drdla labeled with CY5, Drd2 labeled with FITC, and ChAT and pyramidal cells labeled with CY3 (Table 1). Then the sections were washed and mounted onto slides with anti-fading mounting medium and coverslipped (ProLong Antifade Kit P7481, Molecular Probe, Carlsbad, CA, USA). Adjacent sections were stained with cresyl violet to delineate cortical layers.

\section{CONFOCAL MICROSCOPY AND QUANTIFICATION}

Based on functional or anatomical relationship between the MPFC and BF (Golmayo et al., 2003; Vertes, 2004; Henny and Jones, 2008), Cg1, PrL and IL in rats or mice were analyzed. The relationships within layer II/III and V were quantified because they constitute the receiving layer of the cortical input (the thalamic input is almost absent in this cortex) and the output layer, respectively and because the EAAC1 pyramidal cells are present only in these layers. The analysis was conducted on two consecutive coronal sections (rats: +2.76 mm from Bregma (Paxinos and Watson, 1998); mice: (+1.94 to $+1.70 \mathrm{~mm}$ from Bregma; Franklin and Paxinos, 2007) per animal using the Leica SP2 confocal microscope (Leica Microsystems, Wetzlar, Germany). Argon laser (excitation at $488 \mathrm{~nm}$ ) was used for excitation of FITC, Helium Neon laser (excitation at $543 \mathrm{~nm}$ ) was used for excitation of CY3 and Helium Neon laser (excitation at $633 \mathrm{~nm}$ ) was used for excitation of CY5. Z-series of images were taken using $100 \times$ oil lens in sequential scanning mode for each channel and captured by Leica Confocal Software (LCS lite). Z-series of images were randomly taken every $200 \mu \mathrm{m}$, starting at $0.1 \mathrm{~mm}$ above the ventral border of the IL cortex to the dorsal border of $\mathrm{Cg} 1$ in each layer (Figure 1). A projection was defined as a serie of horizontal optical scanning sections in the same image. When a projection was generated, the sampling points of the individual images superimposed along the projection axis were examined throughout all optical sections. In a maximum projection, the maximum intensity value was displayed. Each Z-series maximal projection was composed of an average of three optical sections for fiber microproximity analysis in rats, and four optical sections for the pyramidal cells analysis in rats, to ensure the full capture of pyramidal cells. The step size between any two consecutive optical sections was set at $1 \mu \mathrm{m}$. In total, 28 images were taken for each section ( 6 from IL, 10 from PrL, and 12 from Cg1) and a total of 336 neurons from the six rats were analyzed.
To investigate the anatomical relationship between cholinergic and dopaminergic fibers, a randomly-chosen region of interest (ROI) of $12500.00 \mu \mathrm{m}^{2}$ on the maximum projection of three consecutive optical scanning sections in each image was examined using LCS Lite. Because the step size was set at $1 \mu \mathrm{m}$, the depth of the ROI on this projection was $3 \mu \mathrm{m}$, and the distance between two visible fibers did not span more than $3 \mu \mathrm{m}$ in the $\mathrm{z}$-axis. The total length of dopaminergic (TH) and cholinergic nerve fibers (ChAT) were evaluated in ROIs with ImagePro using manual tracing (Figure 2). The fiber density $\left(\mu \mathrm{m} / \mu \mathrm{m}^{3}\right)$ in each ROI was determined by dividing the total cholinergic or dopaminergic fiber density over the ROI volume. The volume of the ROI on each image was obtained by multiplying the area of the ROI $\left(12500.00 \mu \mathrm{m}^{2}\right)$ with the depth of the ROI.

Cholinergic and dopaminergic fiber microproximity were quantified semi-manually using LCS lite (Figure 1). For convergence of dopaminergic and cholinergic fibers on $\mathrm{mPFC}$ pyramidal neurons, one pyramidal cell per image was analyzed (Figure 1). All single optical scanning sections containing that cell were examined to avoid overcounting. Microproximity for cholinergic, dopaminergic and pyramidal neurons was operationally defined as relationship between axonal segments or axonal segments/pyramidal cell perikaryon with a distance of $3 \mu \mathrm{m}$ or less. This was considered a conservative withinlimit distance for the possibility of occurrence of diffuse transmission given that extracellular ACh may diffuse over short distances and maintain a fast form of non-synaptic transmission, due to the ACh esterase activity and high sensitivity of nAChR (Lendvai and Vizi, 2008; Sarter et al., 2009). As well, DA transmission between elements distant from 2 to $10 \mu \mathrm{m}$ has been shown. The median diffusion distance of dopamine was estimated as $4.8 \mu \mathrm{m}$ in the striatum, and extracellular dopamine concentration was spatially heterogeneous on a dimensional scale commensurate with this diffusion distance of individual dopamine molecules (Peters and Michael, 2000).

The total length of ChAT fibers within microproximity of $\mathrm{TH}$ fibers was measured by manual tracing within each layer of each ROI and the percentage of microproximity per mm of axonal length was calculated. In cases where the microproximity between two fibers did not span more than $3 \mu \mathrm{m}$ on the $x-y$ axis, more than three consecutive optical sections composing the image were examined sequentially to ensure the apposition between the two fibers span more than $3 \mu \mathrm{m}$ in $z$-axis. The same analysis was made for TH fibers in microproximity of ChAT fibers. Furthermore, in order to detect potential activity-related morphological structures of axons, the density and diameter of $\mathrm{TH}$ and ChAT varicosities within or outside the microproximity was evaluated using LCS lite. The varicosities were defined as ellipsoid swelling with a transverse diameter larger than $500 \mathrm{~nm}$ (Mechawar et al., 2000). Fiber segments were analyzed for $\mathrm{TH}$ varicosities within microproximity of ChAT fibers, TH varicosities outside microproximity of ChAT fibers, ChAT varicosities within microproximity of TH fibers, ChAT varicosities outside microproximity of $\mathrm{TH}$ fibers. Fiber segments were randomly analyzed in Layers V and II/III of PrL and Cg1 and IL. In total, 1208 fiber segments were randomly chosen and analyzed in the rat mPFC, with a total length of $10296.65 \mu \mathrm{m}$.

Two mouse brain sections at the level of IL, PrL and Cg1 were analyzed using $100 \times$ oil lens in sequential scanning mode and captured by LCS lite. Two ROI's were randomly chosen within each layer 
A

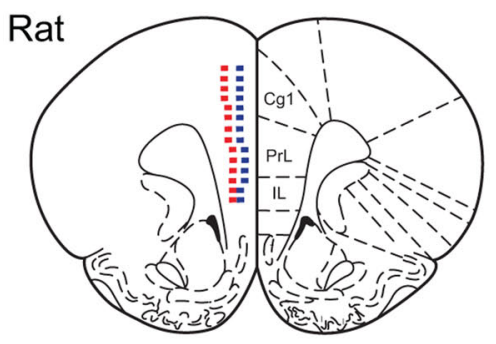

Bregma $2.70 \mathrm{~mm}$

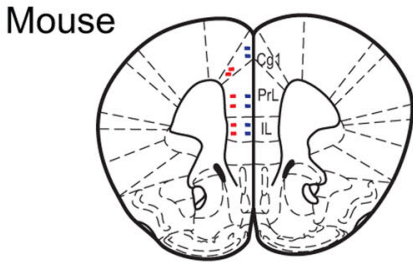

Bregma $1.78 \mathrm{~mm}$

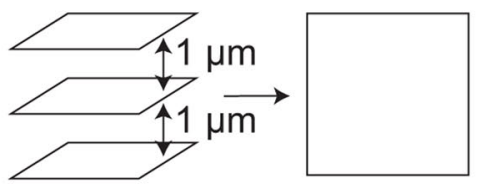

projection

of 3 scanning

sections
D
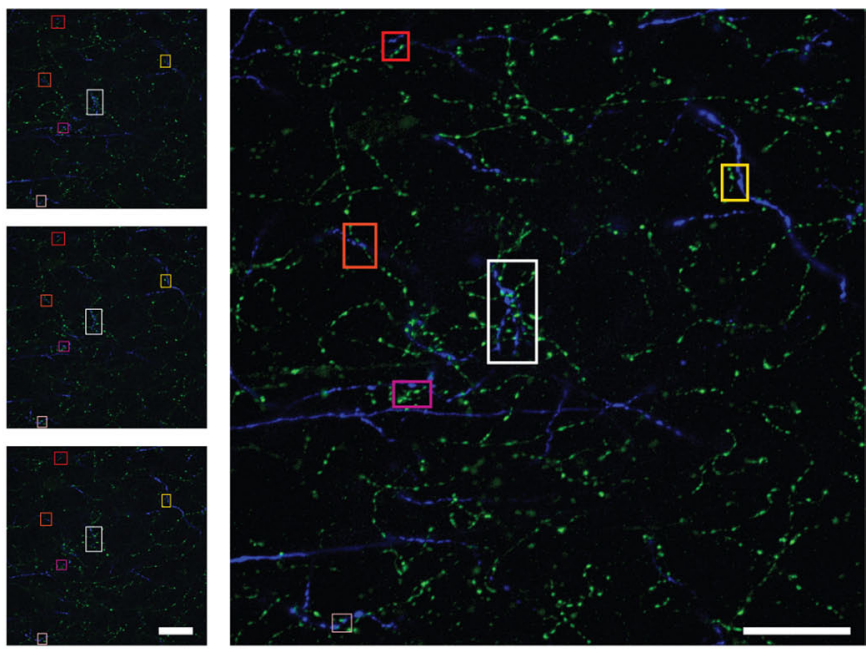

E
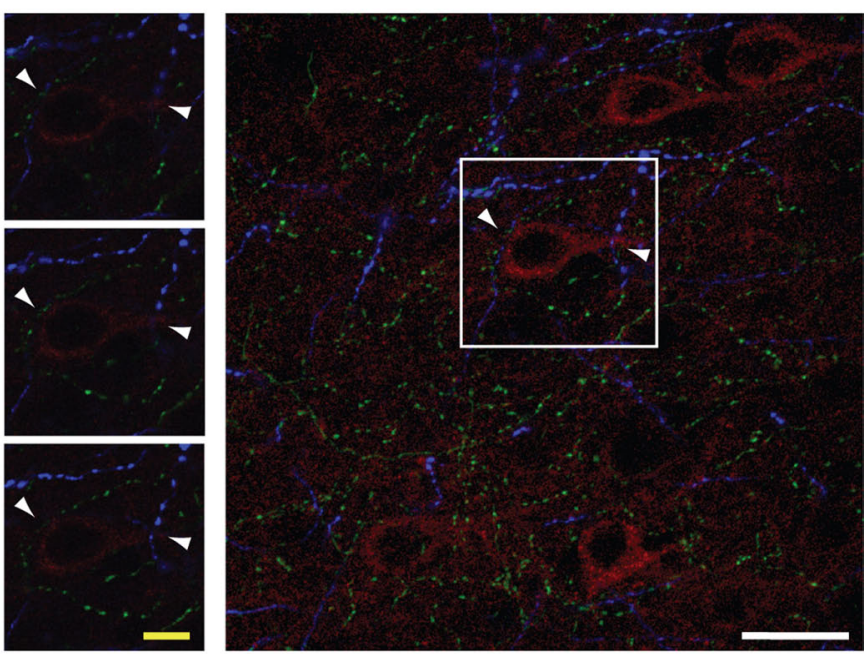

projection of 3 scanning sections
FIGURE 1 | Methodology for quantification of micropoximities with the Leica confocal microscope. Images of the regions of interest (Cg1, PrL, IL) were randomly taken using $100 \times$ oil lens in sequential scanning mode on the coronal sections of rats (A, Bregma, $+2.7 \mathrm{~mm}$ ) and mice (B, Bregma, $+1.8 \mathrm{~mm}$ ). Microphotographs were taken every $200 \mu \mathrm{m}$, starting at $0.1 \mathrm{~mm}$ above the ventral border of the IL cortex to the dorsal border of $\mathrm{Cg} 1$ in each layer

$(\mathbf{A}, \mathbf{B})$. Red squares indicate location of scanning in Layer $\mathrm{V}$, and blue squares indicate location of scanning in Layer II/III. In the BAC Drd1a-tdTomato and
GENSAT BAC Drd2-EGFP double transgenic mice, two images were taken in each layer in each subregion of the MPFC (B). The close appositions (within $3 \mu \mathrm{m}$ in 3D) among cholinergic (green), dopaminergic (blue) fibers, and pyramidal (red) cells were examined on the projection image of three consecutive scanning sections (step size of $1 \mu \mathrm{m}$ ) as well as each single scanning section (C-E). Representative examples of ChAT and TH fibers microproximity are shown (squares in D). Arrows showed examples of pyramidal cells within microproximity of ChAT fibers and TH fibers (E). White scale bar: $25 \mu \mathrm{m}$; Yellow scale bar: $5 \mu \mathrm{m}$. of each subregion. To ensure sufficient sampling through the $z$-axis, sections with triple immunolabeling for $\operatorname{Drd}_{1} \mathrm{a}, \operatorname{Drd}_{2}$, and pyramidal cells were composed of five optical sections, and each section immunolabeled for Drd1a, Drd2, and ChAT fibers was composed of ten optical sections. The step size between any two consecutive optical sections was set at $1 \mu \mathrm{m}$. The images of triple staining of $\operatorname{Drd} 1 a, D r d 2$ and pyramidal cells were exported to Photoshop CS3 and the presence of Drd1 $a$ and Drd2 on pyramidal cells were quantified by manual counting within the ROI. A total of 1810 pyramidal cells were examined. Only pyramidal cells with a clear outline and complete shapes were examined. These pyramidal cells were examined both on the five single optical sections and the overlay projection to ensure validity of the measurements. Colocalization of Drd ${ }_{1}$ and Drd ${ }_{2}$ on the images of triple labeling of Drd1 a, Drd2, and pyramidal cells, as well as Drd1 $a$ and ChAT, and Drd 2 and ChAT on the images of triple immunostaining of $\operatorname{Drd1} a, \mathrm{Drd}$, and ChAT were quantified using the plugin of Intensity Correlation Analysis (Li et al., 2004) in the ImageJ software (Collins, 2007). Mander's Overlap coefficient $(R)$ was used to indicate the colocalization of the two neuronal elements (Manders et al., 1992), with $R$ ranges between 1 and 0 with 1 being high-colocalization and 0 being low. Each single optical section was examined with ImageJ to avoid overcounting. Background was subtracted using areas that did not contain labeled cells or fibers on the same section. 

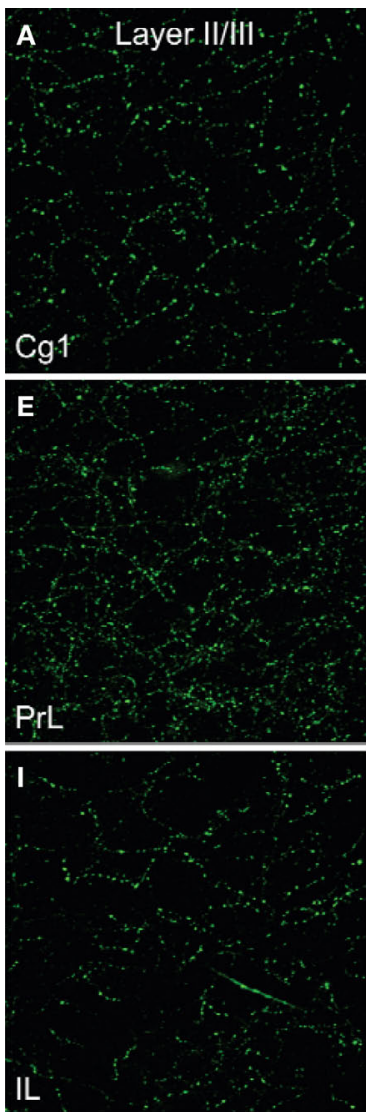

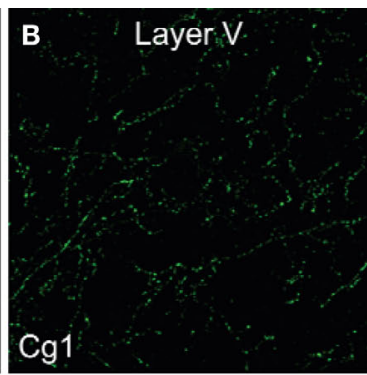

F
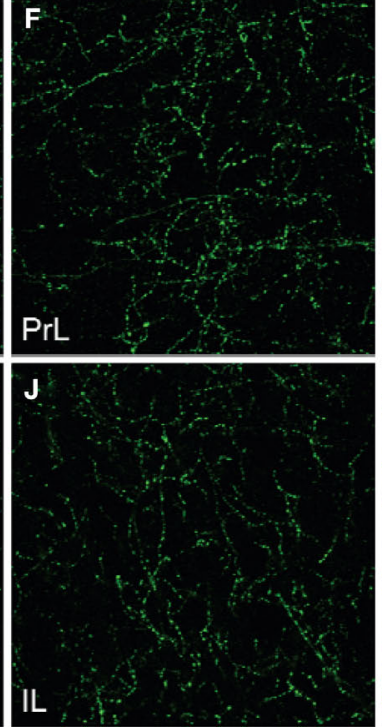
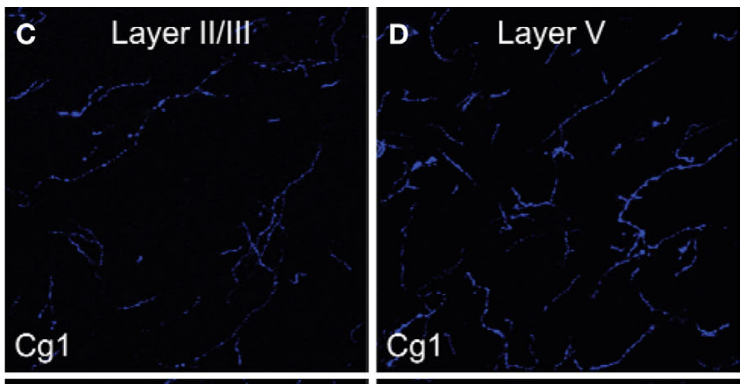

G

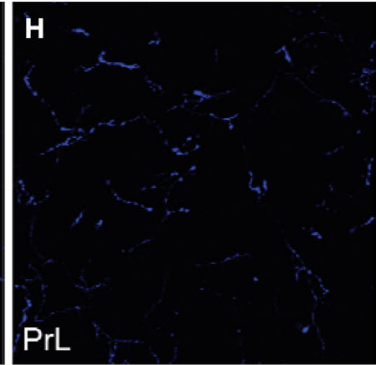

PrL
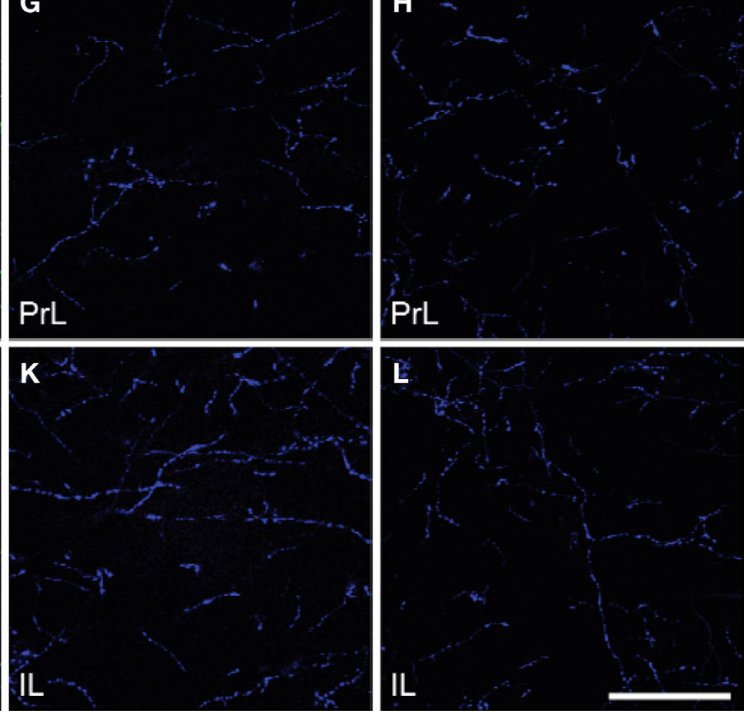

FIGURE 2 | Density of the ChAT (green) fibers (A,B,E,F,I,J) and TH (blue) fibers (C,D,G,H,K,L) in Layer II/III and Layer V of cingulate cortex (Cg1, A-D), prelimbic (PrL, E-H) and infralimbic (IL, I-L) subregions of the medial prefrontal cortex in rats. The density of ChAT fibers was greater than those of TH fibers and showed regional differences. Scale bar: $50 \mu \mathrm{m}$.

\section{STATISTICAL ANALYSIS}

SPSS (17.0) Wilcoxon signed ranks test $(p<0.05$, two tailed) was used to compare the regional effects among IL, PrL and Cg1 and the laminar effects between layer V and layer II/III in the rats and mice. Pearson correlation ( $p<0.05$, two tailed) was used to evaluate the correlation between the incidents of microproximity with fiber density in the rats. Paired student $t$ test $(p<0.05$, two-tailed) was used to compare the density and diameter of varicosities inside microproximity and those outside microproximity, as well as the laminar distribution. An ANOVA ( $p<0.05$, two tailed) was used to evaluate the regional difference in the density and diameter of varicosities.

\section{RESULTS \\ CHOLINERGIC AND DOPAMINERGIC INNERVATION OF IL, PrL AND Cg1 CORTICAL AREAS IN RATS}

Prominent innervations of IL, PrL and Cg1 by both ChAT and TH fibers were observed (Figure 2). The density of TH fibers ranged from $0.008 \mu \mathrm{m} / \mu \mathrm{m}^{3}$ in Cg1 to $0.020 \mu \mathrm{m} / \mu \mathrm{m}^{3}$ in IL, and the density of ChAT fibers ranged from $0.021 \mu \mathrm{m} / \mu \mathrm{m}^{3}$ in $\mathrm{Cg} 1$ to $0.044 \mu \mathrm{m} / \mu \mathrm{m}^{3}$ in PrL (Table 2). ChAT fibers were significantly denser than $\mathrm{TH}$ fibers in most subregions in both layers of mPFC, except in layer $\mathrm{V}$ of IL, where significant level was not reached $(p<0.05)$. Cg1
Table 2 | Dopaminergic and cholinergic fiber density in the mPFC of rats.

$$
\text { Infralimbic Ctx Prelimbic Ctx Cingulate Ctx }
$$

\begin{tabular}{llll}
\hline LAYER II/III & & & \\
TH fiber density & $1.56 \pm 0.32^{+* \neq}$ & $1.35 \pm 0.30^{\dagger *}$ & $0.79 \pm 0.20^{\dagger *}$ \\
ChAT fiber density & $3.53 \pm 1.03^{\dagger * \neq}$ & $4.44 \pm 1.00^{\dagger *+}$ & $2.52 \pm 0.43^{+*}$ \\
LAYER V & & \\
TH fiber density & $1.95 \pm 0.39^{\dagger \neq}$ & $1.79 \pm 0.48^{+*}$ & $0.79 \pm 0.10^{+*}$ \\
ChAT fiber density & $2.50 \pm 0.79^{+\ddagger}$ & $3.24 \pm 0.63^{+* \neq}$ & $2.12 \pm 0.37^{+*}$
\end{tabular}

All values are means \pm SEM expressed in $10^{-2} \mu \mathrm{m} / \mu \mathrm{m}^{3}$ from six animals. Abbreviations: ChAT, choline acetyltransferase; Ctx, cortex; TH, tyrosine hydroxylase.

*Wilcoxon test, $p<0.05$, two-tailed, ChAT vs TH fibers.

${ }^{\dagger}$ Wilcoxon test, $p<0.05$, two-tailed, Region-specific difference.

${ }^{\ddagger}$ Wilcoxon test, $p<0.05$, two-tailed, Layer-specific difference.

had significantly smaller TH and ChAT fiber density compared to IL and PrL in both layers $(p<0.05)$. Part of the ChAT fibers could be attributed to the intracortical cholinergic neurons but this did not represent more than $10 \%$ of the fibers (the ChAT staining was almost absent following BF quisqualic acid lesion; data not shown, but see Vaucher and Hamel, 1995). 

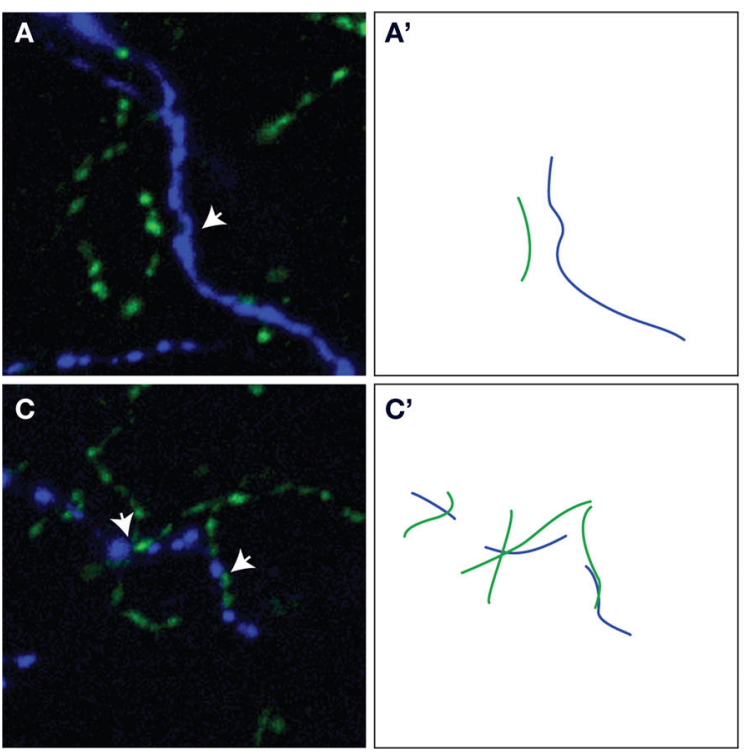
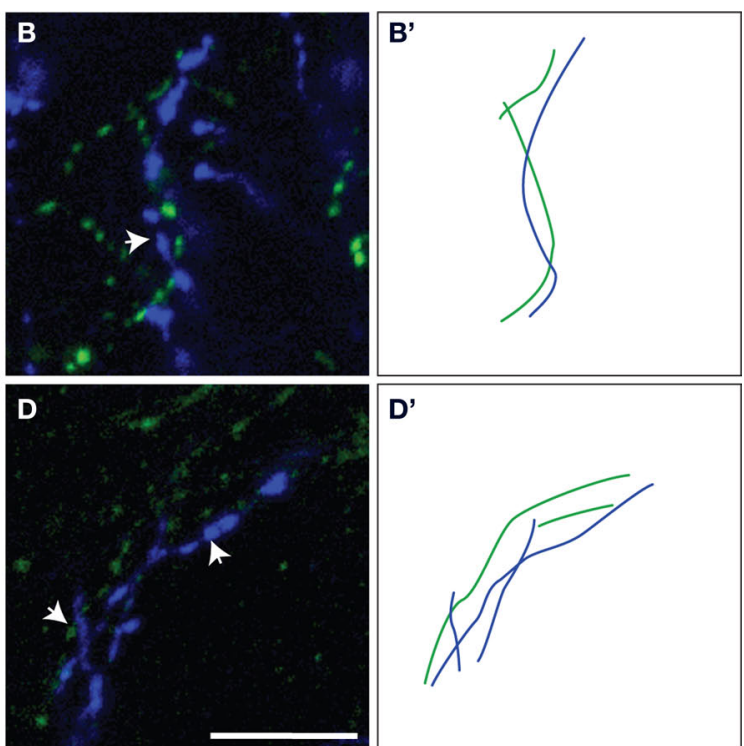

FIGURE 3 | Representative examples of ChAT/TH fibers within microproximity of each other (arrows) (A-D). The measured lengths of microproximity segments are illustrated by drawing of ChAT (green lines) and TH (blue lines) fibers (A'-D'). Scale bar: $5 \mu \mathrm{m}$.

\section{MICROPROXIMITY BETWEEN ChAT AND TH FIBERS IN IL, PrL AND Cg1 OF RATS}

The proportion of the ChAT fibers within the microproximity of TH fibers (Figure 3, Table 3), ranged from 12-18\% in layer V of the rat $\mathrm{mPFC}$ and $8-13 \%$ in layer II/III. Layer V of each subregion in $\mathrm{mPFC}$ had a significantly larger proportion of ChAT fibers close to TH fibers compared to layer II/III $(p<0.05)$, with the exception of IL. In addition, both Cg1 and IL had a significantly larger proportion of ChAT fibers in microproximity to $\mathrm{TH}$ fibers than PrL in both layers V and II/III. In contrast, $21-40 \%$ of the TH fibers in layer $\mathrm{V}$ as well as II/III shared relationship with ChAT fibers (Figure 3; Table 3). Cg1 had a significantly larger proportion of TH fibers in microproximity with ChAT fibers compared to IL or PrL in both layers V and II/III ( $p<0.05)$. In each subregion of each layer in the $\mathrm{mPFC}$, the proportion of TH fibers in microproximity with ChAT fibers was significantly higher than the proportion of ChAT fibers in microproximity to TH fibers, with the exception of Layer V of IL $(p<0.05)$. Because the tortuosity and density of TH and ChAT fibers were different as well as the fiber density for each neuronal system, the length of $\mathrm{TH}$ and ChAT microproximities was not symmetrical.

\section{TH AND ChAT VARICOSITIES DENSITY AND MORPHOLOGY WITHIN THE MICROPROXIMITY SEGMENT OR INTERSEGMENT IN IL, PrL AND Cg1 OF RATS}

The density of both TH and ChAT varicosities (Figure 4) was significantly elevated within microproximity of the other fiber system in each subregion of both Layer V (ChAT: $0.59 \pm 0.03$ per $\mu \mathrm{m}$ of ChAT fiber length; TH: $0.53 \pm 0.04$ per $\mu \mathrm{m}$ of $\mathrm{TH}$ fiber length) and Layer II/III (ChAT: $0.56 \pm 0.03$, TH: $0.52 \pm 0.02$ ) in the rat $\mathrm{mPFC}$ compared to those outside microproximity (ChAT: $0.43 \pm 0.06, \mathrm{TH}: 0.36 \pm 0.03$; $p<0.05$; Table 4; Figure 4). The ChAT varicosity diameter within microproximity $(664 \pm 21 \mathrm{~nm})$ compared to that outside microproximity $(646 \pm 25 \mathrm{~nm})$ was
Table 3 | Microproximity between ChAT and TH fibers in the mPFC of rats.

Infralimbic Ctx Prelimbic Ctx Cingulate Ctx

\begin{tabular}{|c|c|c|c|}
\hline \multicolumn{4}{|l|}{ LAYER II/III } \\
\hline ChAT fibers to $\mathrm{TH}$ fibers & $12.2^{\dagger \neq *}$ & $8.8^{\ddagger * *}$ & $12.3^{\dagger \neq *}$ \\
\hline TH fibers to ChAT fibers & $23.9^{+*}$ & $28.1^{+*}$ & $39.6^{+*}$ \\
\hline \multicolumn{4}{|l|}{ LAYER V } \\
\hline ChAT fibers to TH fibers & $17.9^{\dagger \neq}$ & $12.9^{\dagger \neq *}$ & $15.5^{\dagger \neq *}$ \\
\hline TH fibers to ChAT fibers & $21.4^{\dagger}$ & $22.8^{+*}$ & $40.1^{1 *}$ \\
\hline
\end{tabular}

All values are percentage of axonal segment in microproximity over total fiber length from six animals. Abbreviations: ChAT, choline acetyltransferase; Ctx, cortex; $T H$, tyrosine hydroxylase.

*Wilcoxon test, $p<0.05$, two-tailed, ChAT vs TH fibers.

${ }^{+}$Wilcoxon test, $p<0.05$, two-tailed, Region-specific difference.

${ }^{*}$ Wilcoxon test, $p<0.05$, two-tailed, Layer-specific difference.

significantly larger $(p=0.001)$. The $\mathrm{TH}$ varicosity diameter $(677 \pm 23 \mathrm{~nm})$ within microproximity compared to that outside microproximity was also significantly larger $(p=0.016)$. TH varicosity diameter within microproximity in layer V $(685 \pm 34 \mathrm{~nm})$ was significantly larger than that in layer II/III $(670 \pm 17 \mathrm{~nm}$; $p=0.001$, Table 5).

\section{MICROPROXIMITY BETWEEN PYRAMIDAL CELLS AND CHOLINERGIC AND DOPAMINERGIC FIBERS IN IL, PrL AND Cg1 OF RATS}

The majority of pyramidal cells were found in close proximity with cholinergic fibers both in layer $\mathrm{V}$ and II/III of the three regions examined (Figure 5). In layer V, 78\% of the pyramidal cells examined in IL, 90\% in PrL, and $89 \%$ in Cg1 were in close microproximity with cholinergic fibers (Table 5). In layer II/III these percentages reached $81 \%$ in IL, $87 \%$ in $\operatorname{PrL}$, and $90 \%$ in Cg1. PrL and Cg1 of layer V had significantly more pyramidal cells innervated by ChAT fibers than layer V of IL $(p<0.05)$. As 

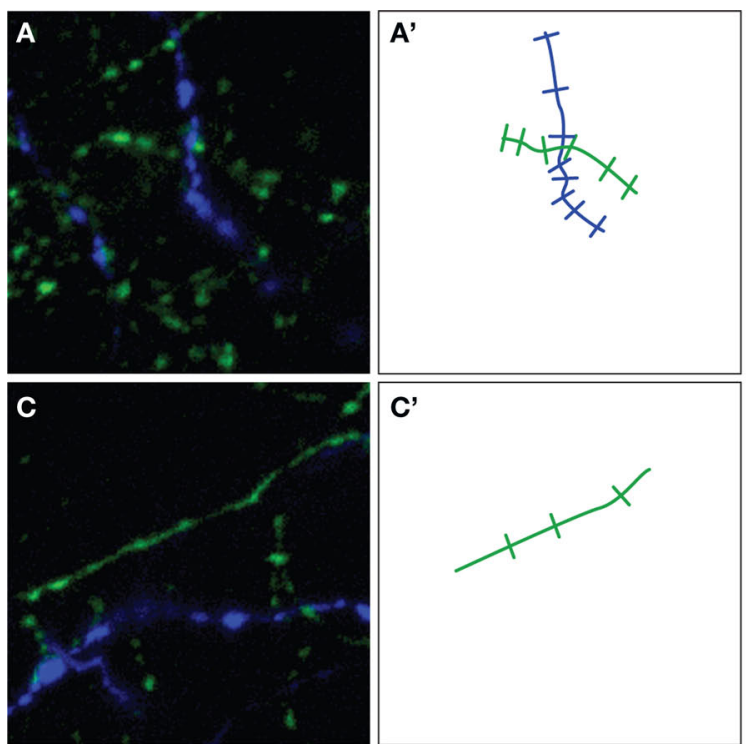

C'
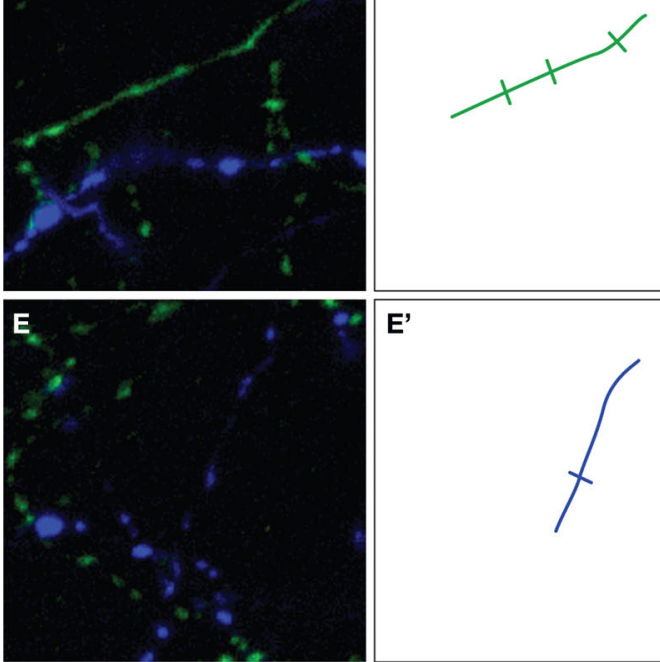

E'
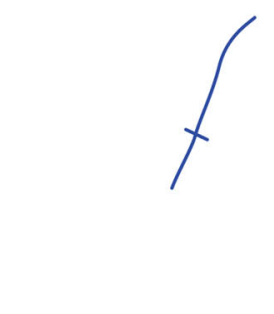

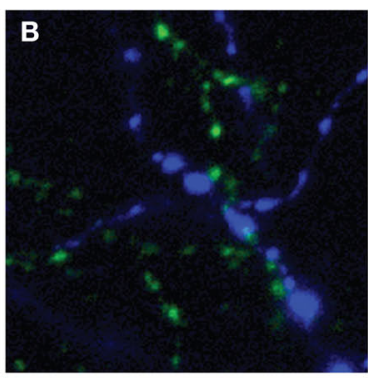

B'
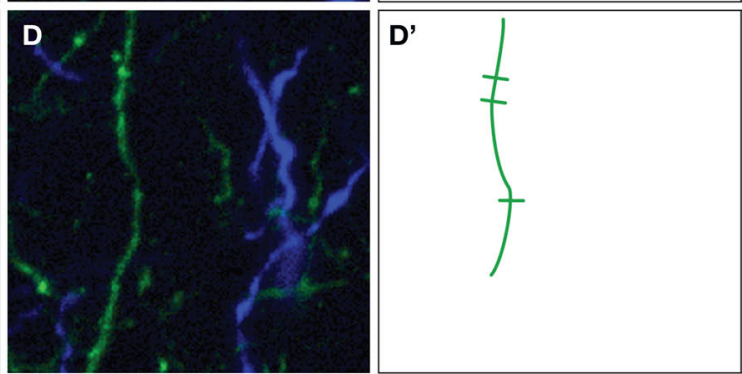

F
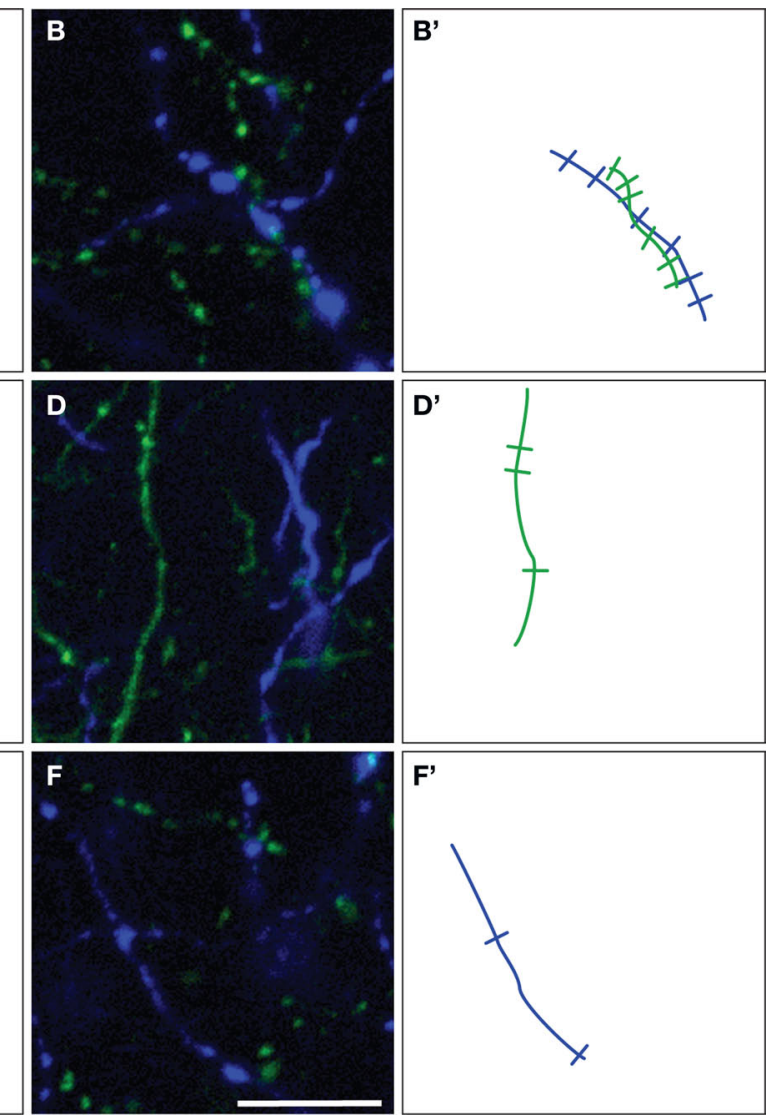

F'
FIGURE 4 | Representative examples of ChAT (green) and TH (blue) varicosities on fiber segments within $(A, B)$ or outside $(C-F)$ the microproximity of the other fiber system in rat $\mathrm{mPFC}$. Note that an increased density of varicosities was seen in segments in microproximity. The number of varicosities counted on microproximity segments are illustrated by indentations on drawing of ChAT (green lines) and TH (blue lines) fibers ( $\left.\mathbf{A}^{\prime}-\mathbf{F}^{\prime}\right)$. Scale bar: $10 \mu \mathrm{m}$. well, the majority of pyramidal cells were found in close proximity with dopaminergic fibers both in layer V and II/III of the three regions examined. In layer $\mathrm{V}, 86 \%$ of pyramidal cells examined in IL, $80 \%$ in PrL, and $87 \%$ in Cg1 were in microproximity with dopaminergic fibers. In layer II/III, these numbers were $69 \%$ in IL, 65\% in PrL, and $61 \%$ in Cg1 (Table 5). There were no regional differences but there was significantly more pyramidal cells innervated by TH fibers in layer V of Cg1 than in Layer II/ III of Cg1 $(p<0.05)$.

Most pyramidal cells examined were within the microproximity of both cholinergic and dopaminergic fibers. In layer $\mathrm{V}, 72 \%$ of pyramidal cells examined in IL, 70\% in PrL, and $80 \%$ in Cg1 showed microproximity with both cholinergic and dopaminergic fibers. In layer II/III these numbers were $64 \%$ in IL, 57\% in PrL, and 56\% in Cg1 (Table 5). There were no regional differences, but there were significantly more pyramidal cells innervated by both ChAT and TH fibers in layer V of Cg1 than in Layer II/III of Cg1 $(p<0.05)$. In layer V, microproximity of cholinergic or dopaminergic fibers with pyramidal cells were observed mainly at the level of the cell soma, less frequently at their apical dendrites and only scarcely at their basal dendrites (Table 6). There was no difference in the preferred localization of the zone of contact of the pyramidal cell by cholinergic or dopaminergic fibers.
The proportion of pyramidal cells innervated by TH and ChAT fibers was not positively correlated with the fiber density in most regions in either layer, indicating that the innervations were not random $(p<0.05$, $r$ ranged from -0.636 to +0.636$)$. The only exception was between the proportion of pyramidal cells innervated by ChAT fibers and ChAT fiber density in Cg1 of layer II/III (Pearson correlation, $p=0.031, r=0.852)$. Moreover, a negative correlation was found between the proportion of pyramidal cells innervated by both fiber systems and TH fiber density in IL of Layer V (Pearson correlation, $p=0.036, r=-0.840)$.

\section{PRESENCE OF D a AND D RECEPTORS ( $D_{1}$ aR AND $D_{2}$ ) ON PYRAMIDAL CELLS AND ChAT FIBERS IN IL, PrL AND Cg1 OF MICE}

Most pyramidal cells ( $~ 92 \%$ to $95 \%$ ) in the mPFC of mice were stained for GFP, i.e. expressing $\mathrm{D}_{2} \mathrm{R}$. However, only a small proportion of pyramidal cells ( $\sim 16 \%$ to $26 \%$ ) were stained for TdTomato, i.e. expressing $\mathrm{D}_{1} \mathrm{aR}$ (Figure 6). About $15 \%$ to $25 \%$ of pyramidal cells expressed both EGFP and TdTomato (Table 7). No significant region-specific or layer-specific difference was found $(p>0.05)$. The expression of either $\mathrm{D}_{1} \mathrm{aR}$ or $\mathrm{D}_{2} \mathrm{R}$ by cholinergic fibers in the subregions of $\mathrm{mPFC}$ of mice was low, with the Mander's coefficient of colocalization of TdTomato and ChAT ranging from $\sim 0.10$ to 0.13 and of GFP and ChAT ranging from 0.22 to 0.27 (Figure 7). No significant region-specific or layer-specific difference was found $(p>0.05)$. 
Table 4 | Number and diameter of TH and ChAT varicosities within or outside microproximity in the $\mathrm{MPFC}$ of rats.

\begin{tabular}{|c|c|c|c|}
\hline & $\begin{array}{l}\text { Infralimbic } \\
\text { Ctx }\end{array}$ & $\begin{array}{l}\text { Prelimbic } \\
\text { Ctx }\end{array}$ & $\begin{array}{l}\text { Cingulate } \\
\text { Ctx }\end{array}$ \\
\hline \multicolumn{4}{|l|}{ LAYER II/III } \\
\hline $\begin{array}{l}\text { TH varicosities within } \\
\text { microproximity }\end{array}$ & $\begin{array}{l}0.52 \pm 0.03^{+} \\
(666 \pm 28)\end{array}$ & $\begin{array}{l}0.53 \pm 0.04^{+*} \\
\left(689 \pm 44^{* \dagger}\right)\end{array}$ & $\begin{array}{l}0.50 \pm 0.04^{\dagger} \\
(656 \pm 44)\end{array}$ \\
\hline $\begin{array}{l}\text { TH varicosities outside } \\
\text { microproximity }\end{array}$ & $\begin{array}{l}0.26 \pm 0.03^{\dagger} \ddagger^{\S} \\
\left(672 \pm 62 \ddagger^{\S}\right)\end{array}$ & $\begin{array}{l}0.33 \pm 0.04^{+*} \ddagger^{\S} \\
\left(608 \pm 37^{+\S}\right)\end{array}$ & $\begin{array}{l}0.31 \pm 0.04^{\dagger \S} \\
\left(601 \pm 12 \ddagger^{\S}\right)\end{array}$ \\
\hline $\begin{array}{l}\text { ChAT varicosities } \\
\text { within microproximity }\end{array}$ & $\begin{array}{l}0.53 \pm 0.01^{\dagger} \\
\left(664 \pm 45^{\S}\right)\end{array}$ & $\begin{array}{l}0.59 \pm 0.03^{+*} \\
\left(641 \pm 09^{*+\S}\right)\end{array}$ & $\begin{array}{l}0.54 \pm 0.04^{\dagger} \\
(641 \pm 23)\end{array}$ \\
\hline $\begin{array}{l}\text { ChAT varicosities outside } \\
\text { microproximity }\end{array}$ & $\begin{array}{l}0.38 \pm 0.13^{\dagger} \\
\left(654 \pm 29^{\S}\right)\end{array}$ & $\begin{array}{l}0.38 \pm 0.02^{+* \S} \\
\left(620 \pm 12^{+\S}\right)\end{array}$ & $\begin{array}{l}0.35 \pm 0.03^{+\S} \\
(626 \pm 24)\end{array}$ \\
\hline \multicolumn{4}{|l|}{ LAYER V } \\
\hline $\begin{array}{l}\text { TH varicosities within } \\
\text { microproximity }\end{array}$ & $\begin{array}{l}0.49 \pm 0.06^{\dagger} \\
(688 \pm 75)\end{array}$ & $\begin{array}{l}0.56 \pm 0.02^{\dagger} \\
(717 \pm 36)\end{array}$ & $\begin{array}{l}0.53 \pm 0.03^{\dagger *} \\
\left(649 \pm 16^{\dagger}\right)\end{array}$ \\
\hline $\begin{array}{l}\text { TH varicosities outside } \\
\text { microproximity }\end{array}$ & $\begin{array}{l}0.33 \pm 0.02^{\dagger} \ddagger^{\S} \\
\left(639 \pm 44 \ddagger^{\S}\right)\end{array}$ & $\begin{array}{l}0.39 \pm 0.04^{+*} \ddagger^{5} \\
\left(697 \pm 40 \ddagger^{\S}\right)\end{array}$ & $\begin{array}{l}0.37 \pm 0.05^{\dagger} \ddagger^{\S} \\
\left(627 \pm 13 \ddagger^{\dagger \S}\right)\end{array}$ \\
\hline $\begin{array}{l}\text { ChAT varicosities within } \\
\text { microproximity }\end{array}$ & $\begin{array}{l}0.57 \pm 0.05^{\dagger} \ddagger \\
\left(665 \pm 21^{\dagger \S}\right)\end{array}$ & $\begin{array}{l}0.61 \pm 0.04^{\dagger} \ddagger \\
\left(704 \pm 35^{\S}\right)\end{array}$ & $\begin{array}{l}0.59 \pm 0.02^{+*} \\
(671 \pm 19)\end{array}$ \\
\hline $\begin{array}{l}\text { ChAT varicosities outside } \\
\text { microproximity }\end{array}$ & $\begin{array}{l}0.36 \pm 0.02^{\dagger} \\
\left(627 \pm 28 \ddagger^{+\S}\right)\end{array}$ & $\begin{array}{l}0.49 \pm 0.06^{+* \S} \\
\left(690 \pm 42 \neq^{\S}\right)\end{array}$ & $\begin{array}{l}0.42 \pm 0.03^{+\S} \\
(657 \pm 26)\end{array}$ \\
\hline
\end{tabular}

All values are means \pm SEM expressed in number of varicosities/ $\mu$ mor (diameter) expressed in $\mathrm{nm}$ from six animals. Abbreviations: ChAT, choline acetyltransferase; Ctx, cortex; $T H$, tyrosine hydroxylase.

*Paired student $t$ test, $p<0.05$, two-tailed, ChAT vs TH varicosities.

${ }^{t}$ Paired student $t$ test, $p<0.05$, two-tailed, within compared outside microproximity.

${ }^{\ddagger}$ One-Way Anova, $p<0.05$, two-tailed, Region-specific difference.

spaired student t test, $p<0.05$, two-tailed, Layer-specific difference.

Table 5 | Percentage of pyramidal cells within the microproximity of ChAT and/orTH fibers in the MPFC of rats.

\begin{tabular}{llll}
\hline & Infralimbic Ctx & Prelimbic Ctx & Cingulate Ctx \\
\hline LAYER II/III & & & \\
ChAT fibers & 80.6 & 86.7 & 90.3 \\
TH fibers & 69.4 & 65.0 & $61.1^{\dagger}$ \\
ChAT and TH fibers & 63.9 & 56.7 & $55.6^{\dagger}$ \\
LAYER V & & & \\
ChAT fibers & $77.8^{*}$ & $90.0^{*}$ & $88.9^{*}$ \\
TH fibers & 86.1 & 80.0 & $87.5^{\dagger}$ \\
ChAT and TH fibers & 72.2 & 70.0 & $80.6^{\dagger}$ \\
\hline
\end{tabular}

All values are mean percentage of pyramidal cells within the microproximity of fibers from six animals.

*Wilcoxon test, $p<0.05$, two-tailed, Region-specific difference in fiber density. ${ }^{\dagger}$ Wilcoxon test, $p<0.05$, two-tailed, Layer-specific difference of fiber density.

\section{DISCUSSION}

The goal of this study was to determine the anatomical potential for a modulatory interaction between cholinergic and $\mathrm{TH}$ afferents in the rodent $\mathrm{mPFC}$ and with the output pyramidal cells. The results indicate that the cholinergic and dopaminergic systems converge on pyramidal cells in mPFC to possibly modulate their activity. The level of dopaminergic fibers relationship with pyramidal cells is higher in the output layer compared to the cortico-cortical connexions layer (layer II/III), whereas cholinergic fibers have the same extent of interaction in layers II/III and V. The mutual axo-axonal microproximity between the two neuronal systems was poor in mPFC. However, the cholinergic system appears to have more influence on the dopaminergic fibers since a larger proportion of the TH fibers are within microproximity to cholinergic fibers and the cholinergic fibers did not express markers of either diar or $\mathrm{d} 2 \mathrm{r}$ expression. Moreover, ChAT fiber segments bore a higher density of varicosities compared to those outside the vicinity of $\mathrm{TH}$ fibers, which could account for an index of improved ACh transmission in these axonal segments. Both ChAT and TH fiber segments bore a higher density of varicosities within microproximity compared to those outside microproximity indicating a potential for elevated transmission at these sites. In addition, in the mPFC of Drd ${ }_{1}$-tdTomato/Drd ${ }_{2}$-EGFP mice, pyramidal cells preferentially expressed markers of the inhibitory $\mathrm{D}_{2} \mathrm{R}$ over $\mathrm{D}_{1} \mathrm{aR}$. The result of the present study suggests an important role in $\mathrm{mPFC}$ output via co-modulation of pyramidal cells by both cholinergic and dopaminergic fibers, and the heterogeneity of the three subregions in $\mathrm{mPFC}$ regarding the neuroanatomical relationship among these three neuronal elements.

\section{ENRICHMENT OF THE MICROPROXIMITIES}

Confocal microscopy offers a means in which to examine the neuroanatomical relationships among individual optical sections at high resolution in sequence through the specimen (Wouterlood et al., 2007; Ichinohe et al., 2008). Here we examined the frequency of microproximities between fibers and pyramidal cells to determine the possible functional interaction between the cholinergic and dopaminergic system in the PFC in the context of diffuse transmission. The primary interest of the current study was to investigate the extracellular microenvironment, where the output of $\mathrm{mPFC}$ is modulated by ACh and DA via diffuse transmission. Synaptic incidents were not counted since ACh terminals rarely form junctional complexes in the neocortex, and only a small proportion of DA varicosities in the neostriatum are synaptic (Descarries et al., $1997,2008)$. Rather, the density of varicosities in segments in microproximity were counted and compared to segments outside of microproximity. We hypothesized that the density of varicosities in an axonal segment could be related to the level of activity, like the experience-induced increase of the number of dendritic spines and axonal synaptic boutons (Stettler et al., 2006). This is in agreement with the hypothesis of the "fast form of non-synaptic transmission" of ACh in the rat mPFC. The criterion definition for the sphere of influence of ACh and DA poses a challenge due to the scarcity of data describing the temporal and spatial parameters of diffuse transmission. The real sphere of influence for a neurotransmitter is limited by a number of factors including the initial number of molecules released, the sensitivity and location of specific receptors, the extracellular volume, the tortuosity of diffusion, the diffusion coefficient of the neurotransmitter, and the regionally distinct uptake mechanisms (Nicholson and Sykova, 1998). To our knowledge diffusion properties of DA and ACh in the extracellular space of $\mathrm{mPFC}$ are unknown. Based on ultrastructural studies (Chedotal et al., 1994; Vaucher and Hamel, 1995) a maximal distance of $3 \mu \mathrm{m}$ between two fibers was used as a conservative 

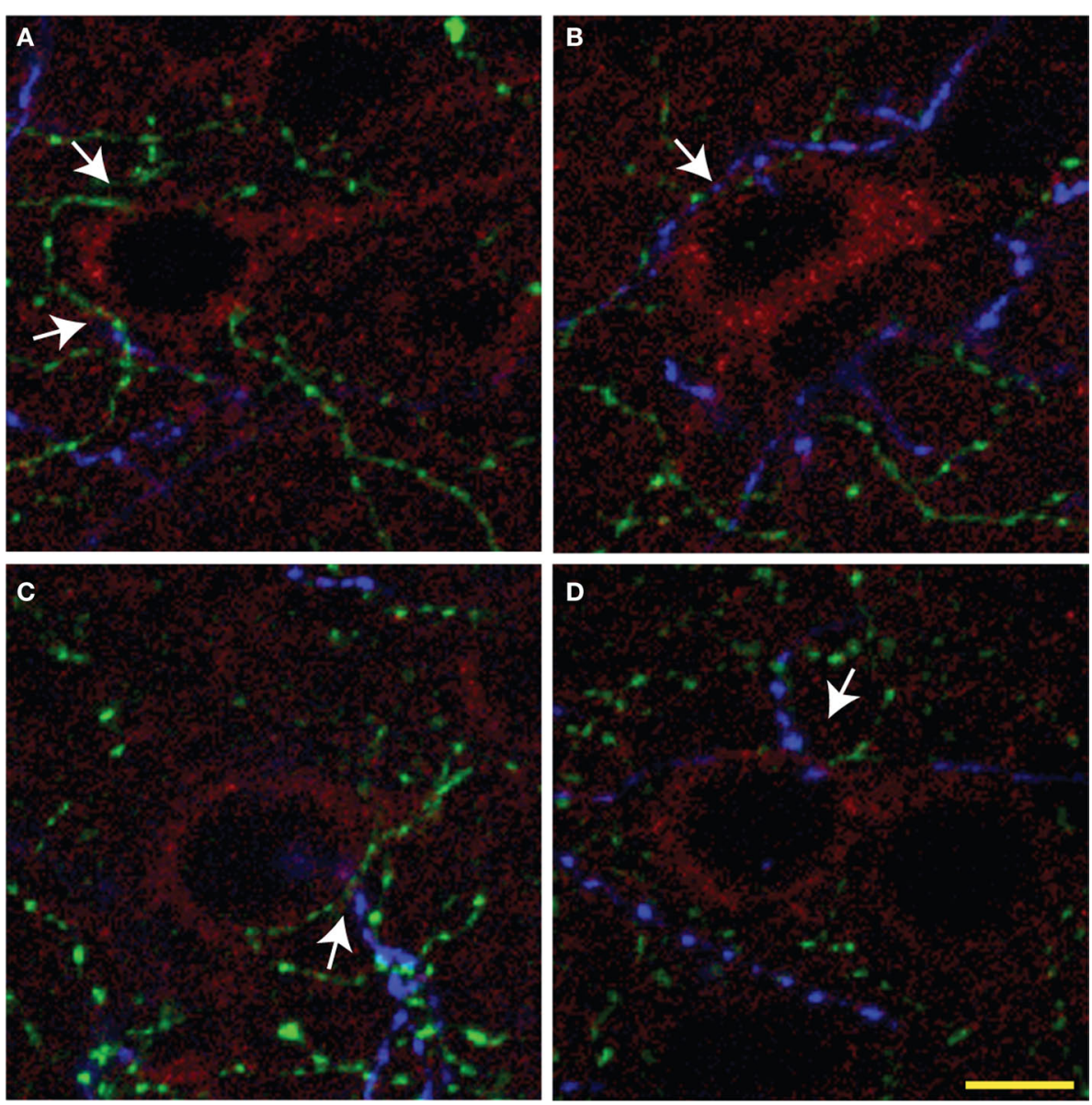

FIGURE 5 | Representative overlay projection images (A-D) of triple immunolabeling of ChAT (green), TH (blue) fibers, and pyramidal cells (red) from three consecutive optic sections in rat mPFC. Arrows show examples of microproximities. Most pyramidal cells were within microproximity of both $\mathrm{ChAT}$ and TH fibers. Scale bar: $5 \mu \mathrm{m}$.

within-limit number for efficient diffuse transmission, i.e. in which neurotransmitter concentration would be sufficient to induce a significant effect, especially taking into consideration the rapid hydrolysis of ACh by AChE (Descarries et al., 1997; Descarries, 1998; Lendvai and Vizi, 2008).

\section{PROPORTION OF ChAT FIBERS WITHIN MICROPROXIMITY OF TH FIBERS}

Mutual interaction between cholinergic and dopaminergic axons characterized by proximity of axons within $3 \mu \mathrm{m}$ could be observed in the mPFC. The frequency of microproximity was moderate for the ChAT fibers (9-18\%) which suggests a weak resultant influence of DA on the cholinergic fibers if any, but quite consistent for the TH fibers (20-40\%). However, the higher density of TH varicosities within the microproximity of ChAT fibers (ranging from 0.49 to 0.56 per $\mu \mathrm{m}$ ), compared to those outside microproximity of ChAT fibers (ranging from 0.26 to 0.39 per $\mu \mathrm{m}$ ) raises the possibility of a DA release site which could modulate ChAT fibers. The value of Mander's coefficient of colocalization of tdTomato linked to the Drd1a promoter or EGFP associated with the Drd2 promoter with ChAT was however low (ranging from 0.10 to 0.25 ), suggesting that the cholinergic fibers were devoid of $\mathrm{D}_{1} \mathrm{aR}$ and $\mathrm{D}_{2} \mathrm{R}$. The lack of clear labeling for markers of dopaminergic receptors might be due to a weak transport of the reporter protein, although the nigrostriatal pathway is well labeled (Shuen et al., 2008). However, the lack of clear labeling of dopaminergic receptors within cholinergic fibers indicates that the pharmacological influence of DA over ACh transmission would take place at the level of pyramidal cells or interneurons rather than in presynaptic modulation of ChAT afferents. It has been shown that DA has an influence on ACh release, which leaves open the potential for a local effect. However, the effect of DA pharmacological agents on ACh transmission might also be exerted through indirect mechanisms when administered systemically, like the involvement of other neurotransmitters systems, instead of local mechanisms. For example, dopaminergic fibers might interact with cholinergic cell bodies in the BF (Smiley et al., 1999) or on glutamatergic input from the nucleus accumbens (Brooks et al., 2007) to exert its influence on projecting cholinergic fibers to the mPFC. Finally, it cannot be excluded that immunodetection of GFP or tdTomato is weaker in the axon compared to the cell body because the gene is expressed in the cell body. While it is possible that the lack of dopaminergic receptors on cholinergic 
fibers might be due to low axonal levels of the reporter protein, axonal tdTomato protein is readily detectable in the striatonigral pathway (Shuen et al., 2008).

\section{HIGHER PROPORTION OF TH FIBERS WITHIN MICROPROXIMITY OF ChAT FIBERS}

The higher proportion of TH fibers in close proximity with ChAT fibers (22-40\%), especially within layer $\mathrm{V}$ would predict a stronger influence of ACh upon dopaminergic transmission. The higher density and size of ChAT varicosities on the fiber segments that are

Table 6 | Percentage of pyramidal cells innervated at their soma/apical dendrites/basal dendrites in LayerV of the MPFC of rats.

\section{Infralimbic Ctx Prelimbic Ctx Cingulate Ctx}

\begin{tabular}{llll}
\multicolumn{2}{l}{ INNERVATION BY CHAT FIBERS } & & \\
Soma & 39.3 & 51.9 & 51.6 \\
Apical dendrites & 28.6 & 35.2 & 37.5 \\
Basal dendrites & 0.0 & 7.4 & 3.1 \\
\multicolumn{2}{l}{ INNERVATION BY TH FIBERS } & & \\
Soma & 54.8 & 64.6 & 54.0 \\
Apical dendrites & 22.6 & 31.3 & 31.8 \\
Basal dendrites & 0.0 & 0.0 & 6.4 \\
\hline
\end{tabular}

All values are means percentage of pyramidal cells innervated at submorphological compartment from six animals. within microproximity to $\mathrm{TH}$ fibers supports the possibility that ACh release modulates $\mathrm{TH}$ fibers in the rat $\mathrm{mPFC}$. Pharmacological evidence also supports the notion that the microproximity of DA and $\mathrm{ACh}$ is functional since local injections of nicotine or increased level of ACh have been shown to increase DA release in $\mathrm{mPFC}$ (Shearman et al., 2005, 2006). The highest proportion of TH and ChAT microproximity occurs in layer V, which suggests that cholinergic fibers modulate the output of mPFC through direct contact to pyramidal cells as well as modulation of DA activity. However, it should be noted that densities and diameters of the varicosities examined under confocal microscope might be slightly overestimated compared to results obtained under electron microscope due to the airy distribution (i.e., a gradient of intensity) of edge of the biological object in bitmapped images (Wouterlood et al., 2007).

\section{COMBINED EFFECTS OF ACh AND DA ON PYRAMIDAL CELLS}

Most pyramidal cells investigated were within the proximity of both cholinergic and dopaminergic fibers. This is consistent with the findings that dopaminergic afferents to the mPFC primarily target the cortical pyramidal cells (Verney et al., 1990). This spatial closeness makes it likely that dopaminergic and cholinergic fibers can modulate mPFC output mostly by innervating the same pyramidal neurons and have a combined effect on pyramidal cell output. In layer V, microproximities between ChAT fibers and TH fibers and pyramidal cells were localized on the soma and apical dendrite. This is consistent with the findings that the majority of the $\mathrm{D}_{1} \mathrm{R}$ and $\mathrm{D}_{2} \mathrm{R}$ are located on cell bodies and dendrites of cells
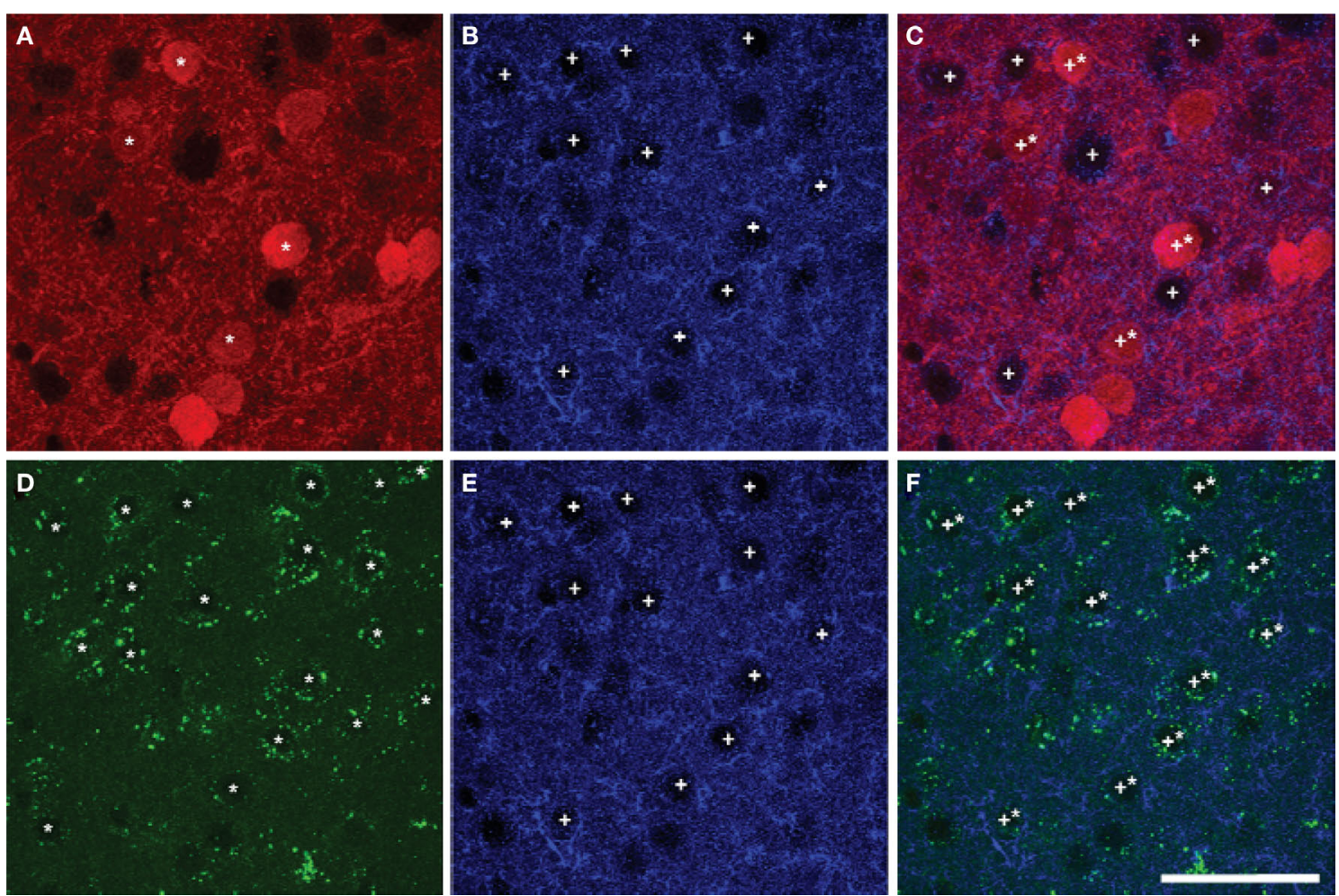

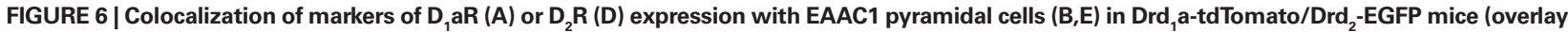
images, C,F). A majority of pyramidal cells expressed Drd ${ }_{2}$ marker (stars in $\mathbf{A}, \mathbf{C}$ ) whereas a minority of pyramidal cells (crosses) expressed Drd1a marker(stars in D,F). Scale bar: $50 \mu \mathrm{m}$. 
intrinsic to the mPFC (Choi et al., 1995; Tzschentke, 2001). There were relatively few microproximities localized on the basal dendrites which is of importance in spike generation (Shu et al., 2007), but the EAAC1 staining was not sensitive enough to label the extent of the dendritic tree. The observed convergence of cholinergic and dopaminergic fibers on pyramidal cells is consistent with various pharmacological evidence supporting the modulation of mPFC pyramidal cells by ACh and DA (Gulledge and Jaffe, 1998; Carr and Surmeier, 2007; Lopez-Gil et al., 2009). Pyramidal cells may integrate inputs from both cholinergic and dopaminergic systems

Table $7 \mid$ Percentage of pyramidal cells containing Drd,a-tdTomato and Drd $_{2}$-EGFP in the mPFC of mice.

\begin{tabular}{llll}
\hline & Infralimbic Ctx & Prelimbic Ctx & Cingulate Ctx \\
\hline LAYER II/III & & & \\
Drd1a & 21.1 & 24.2 & 16.5 \\
Drd2 & 92.6 & 94.4 & 93.3 \\
Drd1a and Drd2 & 21.1 & 23.0 & 15.2 \\
LAYER V & & & \\
Drd1a & 19.3 & 25.6 & 21.5 \\
Drd2 & 94.6 & 92.5 & 92.7 \\
Drd1a and Drd2 & 18.4 & 24.5 & 20.8 \\
\hline
\end{tabular}

All values are mean percentage of pyramidal cells from three Drd,a-TdTomato/ Drd $_{2}$-EGFP transgenic mice. Abbreviations: Ctx, cortex. that in turn transmit and modulate local activity to subcortical target regions. In addition, cholinergic and dopaminergic systems may shape the excitatory output of the mPFC, since neonatal ACh or DA depletion results in layer $\mathrm{V}$ neurons having smaller apical tufts, reduced apical dendrites number/density and reduced basilar spine density. Furthermore, combined ACh/DA depletion produced morphological effects that were additive compared to changes produced by cholinergic and dopaminergic denervation alone (Sherren and Pappas, 2005).

Supporting the neuromodulation of pyramidal cells by DA, are findings in the Drd1a-td Tomato Drd2-EGFP mice which indicate that more than $90 \%$ of the pyramidal cells express Drd 2 and only about $20 \%$ of the pyramidal cells contain Drd1a. Our findings are consistent with previous findings showing that $D_{1} R$ were primarily found on non-pyramidal cells, and that $D_{1} R$ and $D_{2} R$ showed only a partial overlap (Vincent et al., 1993, 1995). About $20 \%$ of the pyramidal cells express markers for both Drd a and $\operatorname{Drd}_{2}$, suggesting a possibility of direct $\mathrm{D}_{1} \mathrm{R}-\mathrm{D}_{2} \mathrm{R}$ association on the same cell (Dziedzicka-Wasylewska et al., 2008). This indicates that dopaminergic transmission on output pyramidal cells might be inhibitory. This is consistent with previous studies showing an excitatory action of DA on GABAergic cells and an inhibitory action on pyramidal cells (Steketee, 2003). In contrast, cholinergic fibers have the same extent of innervation in layers II/III and V. This indicates that ACh might modulate both the excitatory output and input of the mPFC. As ACh enhances neuronal activity, an
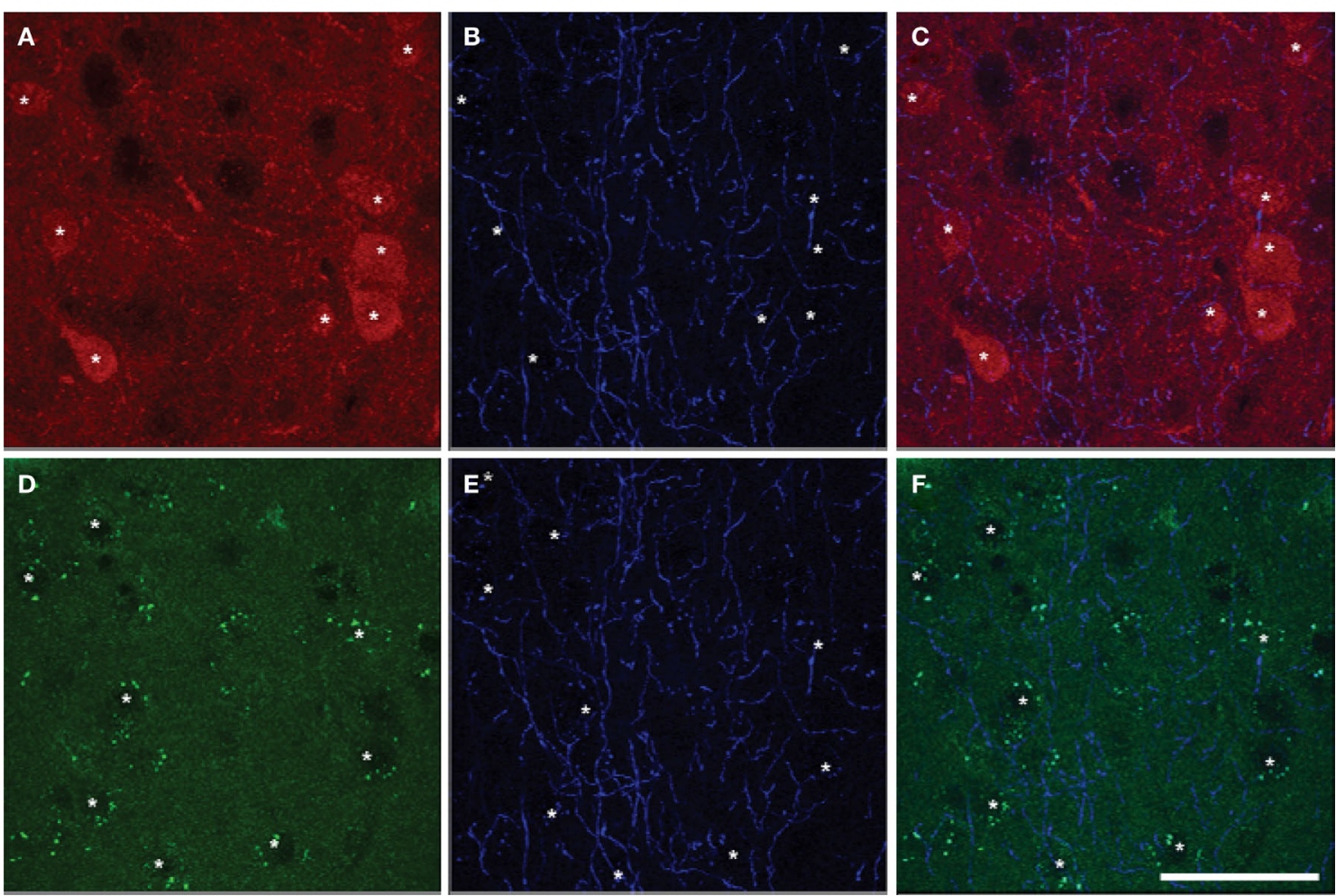

FIGURE 7 | Colocalization of markers of $D_{1} a R(A)$ or $D_{2} R(D)$ expression with ChAT (B,E) in Drd a-tdTomato/Drd - -EGFP mice (overlay images, C,F). The

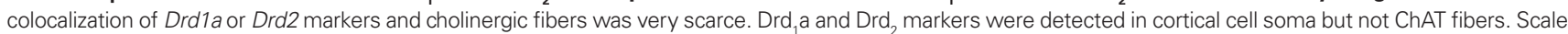
bar: $50 \mu \mathrm{m}$. 
increased cholinergic transmission would enhance the excitatory output of mPFC. However, the concomitant stimulation of TH fibers, which are inhibitory in layer $\mathrm{V}$, would balance the level of output. According to our anatomical data, it can be suggested that the cholinergic afferents exerts an influence on the excitability of the MPFC at both the level of input from associational areas and of output, which can justify an involvement of ACh in retention and orienting, whereas DA would act on impulsivity and selectivity by decreasing the output of layer $\mathrm{V}$ neurons (Steckler et al., 1998).

\section{REGIONAL HETEROGENEITY IN mPFC}

In this study, region-specific differences were found among the three sub-areas in the rat mPFC in terms of the length of ChAT and TH fibers, the incidents of close appositions between cholinergic and dopaminergic fibers, as well as the proportion of pyramidal cells innervated by cholinergic fibers. Regional heterogeneity in rat $\mathrm{mPFC}$ has been a widely-accepted view, and it was shown that IL, PrL and Cg1 each have different extrinsic connections and functions (Broersen et al., 1995; Steckler et al., 1998; Tzschentke, 2001; Heidbreder and Groenewegen, 2003; Thienel et al., 2009). The dense interaction of pyramidal cells with both ChAT and TH fibers in the MPFC did not show any significant differences among the three subregions, implicating the importance of this output mode via co-modulation of pyramidal cells by both ChAT and TH fibers throughout the mPFC. However, more appositions between cholinergic and dopaminergic fibers were found in $\mathrm{Cg} 1$ despite the smallest fiber density in this area, suggesting a stronger interaction between these systems in $\mathrm{Cg} 1$. This is consistent with a lower concentration gradient of extracellular DA in Cg1 compared to IL and dorsal PrL (Sesack et al., 1998; Heidbreder and Groenewegen, 2003). The results also put an emphasis on the relationship of pyramidal cells with cholinergic fibers in layer V of PrL and Cg1,

\section{REFERENCES}

Briand, L. A., Gritton, H., Howe, W. M., Young, D. A., and Sarter, M. (2007). Modulators in concert for cognition: modulator interactions in the prefrontal cortex. Prog. Neurobiol. 83, 69-91.

Broersen, L. M., Heinsbroek, R. P., de Bruin, J. P., Uylings, H. B., and Olivier, B. (1995). The role of the medial prefrontal cortex of rats in short-term memory functioning: further support for involvement of cholinergic, rather than dopaminergic mechanisms. Brain Res. 674, 221-229.

Brooks, J. M., Sarter, M., and Bruno, J. P. (2007). D2-like receptors in nucleus accumbens negatively modulate acetylcholine release in prefrontal cortex. Neuropharmacology 53, 455-463.

Cao, Y. J., Surowy, C. S., and Puttfarcken, P.S. (2005). Different nicotinic acetylcholine receptor subtypes mediating striatal and prefrontal cortical $[3 \mathrm{H}]$ dopamine release. Neuropharmacology $48,72-79$.

Carr, D. B., and Surmeier, D. J. (2007). M1 muscarinic receptor modulation of Kir2 channels enhances temporal summation of excitatory synaptic potentials in prefrontal cortex pyramidal neurons. J. Neurophysiol. 97, 3432-3438.

Chedotal, A., Umbriaco, D., Descarries, L., Hartman, B. K., and Hamel, E. (1994). Light and electron microscopic immunocytochemical analysis of the neurovascular relationships of choline acetyltransferase and vasoactive intestinal polypeptide nerve terminals in the rat cerebral cortex. $J$. Comp. Neurol. 343, 57-71.

Chen, L., Bohanick, J. D., Nishihara, M., Seamans, J. K., and Yang, C. R. (2007). Dopamine D1/5 receptor-mediated long-term potentiation of intrinsic excitability in rat prefrontal cortical neurons: Ca2+-dependent intracellular signaling. J. Neurophysiol. 97, 2448-2464.

Choi, W. S., Machida, C. A., and Ronnekleiv, O. K. (1995). Distribution of dopamine D1, D2, and D5 receptor mRNAs in the monkey brain: ribonuclease protection assay analysis. Brain Res. Mol. Brain Res. 31, 86-94.

suggesting a greater control of the output of these regions by ACh. Pharmacological evidence suggests that an increase in tonic levels of extracellular ACh mediated enhancement of arousal or readiness for input processing in operant tasks testing attention (Briand et al., 2007; Kozak et al., 2007). Since Cg1 is involved in executive functions (Thienel et al., 2009), ACh potentially plays a role in executive function by modulating DA neurotransmission in this area. Finally, the regional difference in function of the PFC could be executed via differences in their connectivity to other brain regions (Steckler et al., 1998; Gabbott et al., 2005; Vertes, 2006; Thienel et al., 2009).

\section{CONCLUSION}

This study has shown that the anatomical positioning between the dopaminergic and cholinergic systems in the mPFC seems to be primarily located at the level of the intracortical cells. Contrary to dopaminergic fibers, cholinergic fibers is positioned to modulate both the input and ouput of $\mathrm{mPFC}$ and influence layer $\mathrm{V}$ pyramidal cells through direct microproximity and influence on dopaminergic fibers. This finding might contribute to improved pharmacological therapies for the treatment of a series of diseases such as schizophrenia, depression, drug abuse, and attention deficit disorders that are associated with improper function of the PFC.

\section{ACKNOWLEDGMENTS}

We wish to thank Florence Dotigny for technical assistance, JeanFrançois Bouchard for contribution to Image analysis, Nathalie Bouchard and Kathye Aubé for their help in the maintenance of the mouse colony. Grant sponsor: Natural Sciences and Engineering Research Council of Canada; Grant number: 238835-07 (Elvire Vaucher). Canadian institute for health research; grant number: 93798 (Jean-Martin Beaulieu). Jean-Martin Beaulieu holds a Canada research Chair in Molecular Psychiatry.

Chudasama, Y., Dalley, J. W., Nathwani, F., Bouger, P., and Robbins, T. W. (2004). Cholinergic modulation of visual attention and working memory: dissociable effects of basal forebrain 192-IgG-saporin lesions and intraprefrontal infusions of scopolamine. Learn. Mem. 11, 78-86.

Collins, T. J. (2007). ImageJ for microscopy. BioTechniques 43, 25-30.

Dalley, J. W., Theobald, D. E., Bouger, P., Chudasama, Y., Cardinal, R. N., and Robbins, T. W. (2004). Cortical cholinergic function and deficits in visual attentional performance in rats following 192 IgG-saporininduced lesions of the medial prefrontal cortex. Cereb. Cortex 14, 922-932.

Del Arco, A., and Mora, F. (2009). Neurotransmitters and prefrontal cortex-limbic system interactions: implications for plasticity and psychiatric disorders. J. Neural Transm. 116, 941-952.

Descarries, L. (1998). The hypothesis of an ambient level of acetylcholine in the central nervous system. J. Physiol. Paris 92, 215-220.

Descarries, L., Berube-Carriere, N., Riad, M., Bo, G. D., Mendez, J. A., and Trudeau, L. E. (2008). Glutamate in dopamine neurons: synaptic versus diffuse transmission. Brain Res. Rev. 58, 290-302.

Descarries, L., Gisiger, V., and Steriade, M. (1997). Diffuse transmission by acetylcholine in the CNS. Prog. Neurobiol. 53, 603-625.

Descarries, L., and Mechawar, N. (2000). Ultrastructural evidence for diffuse transmission by monoamine and acetylcholine neurons of the central nervous system. Prog. Brain Res. 125, 27-47.

Di Cara, B., Panayi, F., Gobert,A., Dekeyne, A., Sicard,D., De Groote, L., and Millan, M. J. (2007). Activation of dopamine D1 receptors enhances cholinergic transmission and social cognition: a parallel dialysis and behavioural study in rats. Int. J. Neuropsychopharmacol. 10, 383-399.

Dotigny, F., Ben Amor,A.Y., Burke, M., and Vaucher, E. (2008). Neuromodulatory 
role of acetylcholine in visually-induced cortical activation: behavioral and neuroanatomical correlates. Neuroscience 154, 1607-1618.

Dziedzicka-Wasylewska, M., FaronGorecka, A., Gorecki, A., and Kusemider, M. (2008). Mechanism of action of clozapine in the context of dopamine D1-D2 receptor heterodimerization-a working hypothesis. Pharmacol. Rep. 60, 581-587.

Franklin, K., and Paxinos, G. (2007). The Mouse Brain in Stereotaxic Coordinates. Amsterdam: Elsevier Inc.

Furuta, A., Noda, M., Suzuki, S. O., Goto, Y., Kanahori, Y., Rothstein, J. D., and Iwaki, T. (2003). Translocation of glutamate transporter subtype excitatory amino acid carrier 1 protein in kainic acid-induced rat epilepsy. Am. J. Pathol. 163, 779-787.

Gabbott, P. L., Warner, T. A., Jays, P. R., Salway, P., and Busby, S. J. (2005). Prefrontal cortex in the rat: projections to subcortical autonomic, motor, and limbic centers. J. Comp. Neurol. 492, 145-177.

Gill, T. M., Sarter, M., and Givens, B. (2000). Sustained visual attention performance-associated prefrontal neuronal activity: evidence for cholinergic modulation. J. Neurosci. 20, 4745-4757.

Golmayo, L., Nunez, A., and Zaborszky, L. (2003). Electrophysiological evidence for the existence of a posterior cortical-prefrontal-basal forebrain circuitry in modulating sensory responses in visual and somatosensory rat cortical areas. Neuroscience 119, 597-609.

Gong, S., Zheng, C., Doughty, M. L., Losos, K., Didkovsky, N., Schambra, U. B., Nowak, N. J., Joyner, A., Leblanc, G., Hatten, M. E., and Heintz, N. (2003). A gene expression atlas of the central nervous system based on bacterial artificial chromosomes. Nature 425, 917-925.

Goto, Y., and Grace, A. A. (2005). Dopamine-dependent interactions between limbic and prefrontal cortical plasticity in the nucleus accumbens: disruption by cocaine sensitization. Neuron 47, 255-266.

Goto, Y., Otani, S., and Grace, A. A. (2007). The Yin and Yang of dopamine release: a new perspective. Neuropharmacology 53, 583-587.

Granon, S., Passetti, F., Thomas, K. L., Dalley, J. W., Everitt, B. J., and Robbin, T. W. (2000). Enhanced and impaired attentional performance after infusion of D1 dopaminergic receptor agents into rat prefrontal cortex. J. Neurosci. 20, 1208-1215.

Gulledge, A. T., and Jaffe, D. B. (1998). Dopamine decreases the excitability of layer $\mathrm{V}$ pyramidal cells in the rat prefrontal cortex. J. Neurosci. 18, 9139-9151.

He, Y., Janssen, W. G., Rothstein, J. D., and Morrison, J. H. (2000). Differential synaptic localization of the glutamate transporter EAAC1 and glutamate receptor subunit GluR2 in the rat hippocampus. J. Comp. Neurol. 418, 255-269.

Heidbreder, C. A., and Groenewegen, H. J. (2003). The medial prefrontal cortex in the rat: evidence for a dorso-ventral distinction based upon functional and anatomical characteristics. Neurosci. Biobehav. Rev. 27, 555-579.

Henny, P., and Jones, B. E. (2008). Projections from basal forebrain to prefrontal cortex comprise cholinergic, GABAergic and glutamatergic inputs to pyramidal cells or interneurons. Eur. J. Neurosci. 27, 654-670.

Ichinohe, N., Hyde, J., Matsushita, A., Ohta, K., and Rockland, K. S. (2008). Confocal mapping of cortical inputs onto identified pyramidal neurons. Front. Biosci. 13, 6354-6373.

Ichikawa, J., Chung, Y. C., Li, Z., Dai, J., and Meltzer, H.Y. (2002). Cholinergic modulation of basal and amphetamine-induced dopamine release in rat medial prefrontal cortex and nucleus accumbens. Brain Res. 958, 176-184.

Kozak, R., Martinez, V., Young, D., Brown, H., Bruno, J. P., and Sarter, M. (2007). Toward a neuro-cognitive animal model of the cognitive symptoms of schizophrenia: disruption of cortical cholinergic neurotransmission following repeated amphetamine exposure in attentional task-performing, but not non-performing, rats. Neuropsychopharmacology 32, 2074-2086.

Lacroix, L. P., Ceolin, L., Zocchi, A., Varnier, G., Garzotti, M., Curcuruto, O., and Heidbreder, C. A. (2006). Selective dopamine D3 receptor antagonists enhance cortical acetylcholine levels measured with highperformance liquid chromatography/ tandem mass spectrometry without anti-cholinesterases. J. Neurosci. Methods 157, 25-31.

Lapish, C. C., Kroener, S., Durstewitz, D., Lavin, A., and Seamans, J. K. (2007). The ability of the mesocortical dopamine system to operate in distinct temporal modes. Psychopharmacology (Berl.) 191, 609-625.

Laplante, F., Srivastava, L. K., and Quirion, R. (2004). Alterations in dopaminergic modulation of prefrontal cortical acetylcholine release in post-pubertal rats with neonatal ventral hippocampal lesions. J. Neurochem. 89, 314-323.

Lendvai, B., and Vizi, E. S. (2008). Nonsynaptic chemical transmission through nicotinic acetylcholine receptors. Physiol. Rev. 88, 333-349.
Li, Q., Lau, A., Morris, T. J., Guo, L., Fordyce, C. B., and Stanley, E. F. (2004). A syntaxin 1, Galpha(o), and $\mathrm{N}$-type calcium channel complex at a presynaptic nerve terminal: analysis by quantitative immunocolocalization. $J$. Neurosci. 24, 4070-4081.

Li, Z., Bonhaus, D. W., Huang, M., Prus, A. J., Dai, J., and Meltzer, H. Y. (2007) AC260584 (4-[3-(4-butylpiperidin-1yl)-propyl]-7-fluoro-4H-benzo[1,4] oxazin-3-one), a selective muscarinic M1 receptor agonist, increases acetylcholine and dopamine release in rat medial prefrontal cortex and hippocampus. Eur. J. Pharmacol. 572 , 129-137.

Lopez-Gil, X., Artigas, F., and Adell, A. (2009). Role of different monoamine receptors controlling MK-801induced release of serotonin and glutamate in the medial prefrontal cortex: relevance for antipsychotic action. Int. J. Neuropsychopharmacol. 12, 487-499.

Manders, E. M., Stap, J., Brakenhoff, G. J., van Driel, R., and Aten, J. A. (1992). Dynamics of three-dimensional replication patterns during the S-phase, analysed by double labelling of DNA and confocal microscopy. J. Cell. Sci. 103 ( Pt 3), 857-862.

Mechawar,N., Cozzari, C., and Descarries, L. (2000). Cholinergic innervation in adult rat cerebral cortex: a quantitative immunocytochemical description. $J$. Comp. Neurol. 428, 305-318.

Miner, L. H., Schroeter, S., Blakely, R. D. and Sesack,S.R. (2003). Ultrastructural localization of the norepinephrine transporter in superficial and deep layers of the rat prelimbic prefrontal cortex and its spatial relationship to probable dopamine terminals. $J$. Comp. Neurol. 466, 478-494.

Nicholson, C., and Sykova, E. (1998). Extracellular space structure revealed by diffusion analysis. Trends Neurosci. 21, 207-215.

Onn, S. P., Wang, X. B., Lin, M., and Grace, A. A. (2006). Dopamine D1 and D4 receptor subtypes differentially modulate recurrent excitatory synapses in prefrontal cortical pyramidal neurons. Neuropsychopharmacology 31 , 318-338.

Paxinos, G., and Watson, C. (1998). The Rat Brain in Stereotaxic Coordinates. San Diego: Elsevier Inc.

Perry, K. W., Nisenbaum, L. K., George, C. A., Shannon, H. E., Felder, C. C., and Bymaster, F. P. (2001). The muscarinic agonist xanomeline increases monoamine release and immediate early gene expression in the rat prefrontal cortex. Biol. Psychiatry 49 716-725.

Peters, J. L., and Michael, A. C. (2000). Changes in the kinetics of dopamine release and uptake have differential effects on the spatial distribution of extracellular dopamine concentration in rat striatum. J. Neurochem. 74 , 1563-1573.

Rao, T. S., Correa, L. D., Adams, P., Santori, E. M., and Sacaan, A. I. (2003). Pharmacological characterization of dopamine, norepinephrine and serotonin release in the rat prefrontal cortex by neuronal nicotinic acetylcholine receptor agonists. Brain Res. 990, 203-208.

Robbins, T. W. (2005). Chemistry of the mind: neurochemical modulation of prefrontal cortical function. J. Comp. Neurol. 493, 140-146.

Rossi, S., Singer, S., Shearman, E., Sershen, H., and Lajtha, A. (2005). The effects of cholinergic and dopaminergic antagonists on nicotine-induced cerebral neurotransmitter changes. Neurochem. Res. 30, 541-558.

Rotaru, D. C., Lewis, D. A., and GonzalezBurgos, G. (2007). Dopamine D1 receptor activation regulates sodium channel-dependent EPSP amplification in rat prefrontal cortex pyramidal neurons. J. Physiol. (Lond.) 581, 981-1000.

Rothstein, J. D., Martin, L., Levey, A. I. Dykes-Hoberg, M., Jin, L., Wu, D., Nash, N., and Kuncl, R. W. (1994). Localization of neuronal and glial glutamate transporters. Neuron 13 , 713-725.

Sarter, M., Bruno, J. P., and Givens, B. (2003). Attentional functions of cortical cholinergic inputs: what does it mean for learning and memory? Neurobiol. Learn. Mem. 80, 245-256.

Sarter, M., Gehring, W. J., and Kozak, R. (2006). More attention must be paid: the neurobiology of attentional effort. Brain Res. Rev. 51, 145-160.

Sarter, M., Hasselmo, M. E., Bruno, J. P., and Givens, B. (2005). Unraveling the attentional functions of cortical cholinergic inputs: interactions between signal-driven and cognitive modulation of signal detection. Brain Res. Brain Res. Rev. 48, 98-111.

Sarter, M., Parikh, V., and Howe, W. M. (2009). Phasic acetylcholine release and the volume transmission hypothesis: time to move on. Nat. Rev. Neurosci. 10, 383-390.

Sesack, S. R., Hawrylak, V. A., Matus, C., Guido, M. A., and Levey, A. I. (1998). Dopamine axon varicosities in the prelimbic division of the rat prefrontal cortex exhibit sparse immunoreactivity for the dopamine transporter. $J$. Neurosci. 18, 2697-2708.

Shearman, E., Rossi, S., Sershen, H., Hashim, A., and Lajtha, A. (2005). Locally administered low nicotineinduced neurotransmitter changes in 
areas of cognitive function. Neurochem. Res. 30, 1055-1066.

Shearman, E., Rossi, S., Szasz, B., Juranyi, Z., Fallon, S., Pomara, N., Sershen, H., and Lajtha, A. (2006). Changes in cerebral neurotransmitters and metabolites induced by acute donepezil and memantine administrations: a microdialysis study. Brain Res. Bull. 69, 204-213.

Sherren, N., and Pappas, B. A. (2005). Selective acetylcholine and dopamine lesions in neonatal rats produce distinct patterns of cortical dendritic atrophy in adulthood. Neuroscience 136, 445-456.

Shu, Y., Duque, A., Yu, Y., Haider, B., and McCormick, D. A. (2007). Properties of action-potential initiation in neocortical pyramidal cells: evidence from whole cell axon recordings. $J$. Neurophysiol. 97, 746-760.

Shuen, J. A., Chen, M., Gloss, B., and Calakos, N. (2008). Drd1a-tdTomato BAC transgenic mice for simultaneous visualization of medium spiny neurons in the direct and indirect pathways of the basal ganglia. J. Neurosci. 28, 2681-2685.

Smiley, J. F., Subramanian, M., and Mesulam, M. M. (1999). Monoaminergic-cholinergic interactions in the primate basal forebrain. Neuroscience 93, 817-829.

Spruston, N. (2008). Pyramidal neurons: dendritic structure and synaptic integration. Nat. Rev. Neurosci. 9, 206-221.

Steckler, T., Sahgal, A., Aggleton, J. P., and Drinkenburg, W. H. (1998).
Recognition memory in rats-III. Neurochemical substrates. Prog. Neurobiol. 54, 333-348.

Steketee, J. D. (2003). Neurotransmitter systems of the medial prefrontal cortex: potential role in sensitization to psychostimulants. Brain Res. Brain Res. Rev. 41, 203-228.

Stettler, D. D., Yamahachi, H., Li, W., Denk, W., and Gilbert, C. D. (2006). Axons and synaptic boutons are highly dynamic in adult visual cortex. Neuron 49, 877-887.

Tavares, R. F., and Correa, F. M. (2006). Role of the medial prefrontal cortex in cardiovascular responses to acute restraint in rats. Neuroscience 143 , 231-240.

Thienel, R., Voss, B., Kellermann, T., Reske, M.,Halfter,S.,Sheldrick,A.J.,Radenbach, K., Habel, U., Shah, N. J., Schall, U., and Kircher, T. (2009). Nicotinic antagonist effects on functional attention networks. Int. J. Neuropsychopharmacol. 12, 1295-1305.

Tzschentke, T. M. (2001). Pharmacology and behavioral pharmacology of the mesocortical dopamine system. Prog. Neurobiol. 63, 241-320.

Vaucher, E., and Hamel, E. (1995). Cholinergic basal forebrain neurons project to cortical microvessels in the rat: electron microscopic study with anterogradely transported Phaseolus vulgaris leucoagglutinin and choline acetyltransferase immunocytochemistry. J. Neurosci. 15, 7427-7441.

Vaucher, E., Linville, D., and Hamel, E. (1997). Cholinergic basal forebrain projections to nitric oxide synthasecontaining neurons in the rat cerebral cortex. Neuroscience 79, 827-836.

Verney, C., Alvarez, C., Geffard, M., and Berger, B. (1990). Ultrastructural double-labelling study of dopamine terminals and GABA-containing neurons in rat anteromedial cerebral cortex. Eur. J. Neurosci. 2, 960-972.

Vertes, R. P. (2004). Differential projections of the infralimbic and prelimbic cortex in the rat. Synapse 51, 32-58.

Vertes, R. P. (2006). Interactions among the medial prefrontal cortex, hippocampus and midline thalamus in emotional and cognitive processing in the rat. Neuroscience 142, 1-20.

Vidal, C., and Changeux, J. P. (1993). Nicotinic and muscarinic modulations of excitatory synaptic transmission in the rat prefrontal cortex in vitro. Neuroscience 56, 23-32.

Vincent, S. L., Khan, Y., and Benes, F. M. (1993). Cellular distribution of dopamine $\mathrm{D} 1$ and $\mathrm{D} 2$ receptors in rat medial prefrontal cortex. J. Neurosci. 13, 2551-2564.

Vincent,S.L., Khan,Y., andBenes,F.M.(1995). Cellular colocalization of dopamine D1 and $\mathrm{D} 2$ receptors in rat medial prefrontal cortex. Synapse 19, 112-120.

Wouterlood, F. G., Boekel, A. J., Meijer, G. A., and Belien, J.A. (2007). Computerassisted estimation in the CNS of 3D multimarker 'overlap' or 'touch' at the level of individual nerve endings: a confocal laser scanning microscope application. J. Neurosci. Res. 85 1215-1228.
Yamasaki,M., Matsui, M., and Watanabe, M. (2010). Preferential localization of muscarinic $\mathrm{ml}$ receptor on dendritic shaft and spine of cortical pyramidal cells and its anatomical evidence for volume transmission. J. Neurosci. 30, 4408-4418.

Yang, C. R., and Mogenson, G. J. (1990) Dopaminergic modulation of cholinergic responses in rat medial prefrontal cortex: an electrophysiological study. Brain Res. 524, 271-281.

Conflict of Interest Statement: The authors declare that the research was conducted in the absence of any commercial or financial relationships that could be construed as a potential conflict of interest.

Received: 06 April 2010; paper pending published: 20 April 2010; accepted: 05 May 2010; published online: 14 June 2010.

Citation: Zhang ZW, Burke MW, CalakosN, BeaulieuJMand VaucherE (2010) Confocal analysis of cholinergic and dopaminergic inputs onto pyramidal cells in the prefrontal cortex of rodents. Front. Neuroanat. 4:21. doi: 10.3389/fnana.2010.00021 Copyright (c) 2010 Zhang, Burke, Calakos, Beaulieu and Vaucher. This is an openaccess article subject to an exclusive license agreement between the authors and the Frontiers Research Foundation, which permits unrestricted use, distribution, and reproduction in any medium, provided the original authors and source are credited. 